Working Paper Series

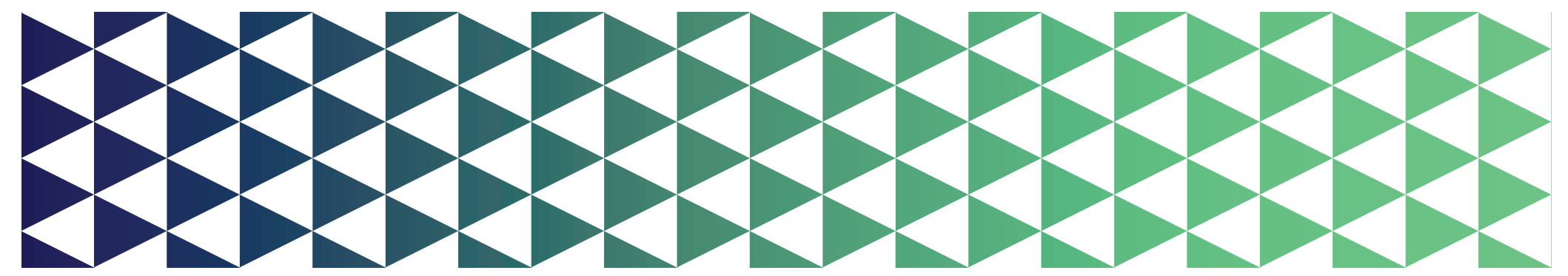

No. $01 / 2018$

Shock Contagion, Asset Quality and Lending Behavior

Tho Pham

Oleksandr Talavera

Andriy Tsapin 


\section{National Bank of Ukraine Working Paper Series:}

The Working Paper Series of the National Bank of Ukraine (NBU) presents the independent research of the staff of the NBU or outside contributors on topics relevant to central banks. The purpose of the Working Papers is to provide the platform for discussion and critical comments. The Working Papers are reviewed internationally to ensure the high quality of the content. The opinions and conclusions in the papers are strictly those of author(s) and do not necessarily reflect the views of the National Bank of Ukraine or of the Board members.

This publication is available on the NBU website at http://www.bank.gov.ua.

\section{Address:}

9 Instytutska Street, 01601, Kyiv, Ukraine email: research@bank.gov.ua

(c) National Bank of Ukraine, 2018.

Reproduction is permitted provided that the source is acknowledged 


\title{
SHOCK CONTAGION, ASSET QUALITY AND LENDING BEHAVIOR
}

\author{
Tho Pham ${ }^{\mathrm{a}} \quad$ Oleksandr Talavera ${ }^{\mathrm{b}} \quad$ Andriy Tsapin ${ }^{\mathrm{cd}}$ \\ January 2018
}

\begin{abstract}
We use the geopolitical conflict in eastern Ukraine as a negative shock to bank assets and examine the shock's impact on the banking sector. We find banks were more severely affected by the conflict if they had more loans outstanding in the conflict areas before the shock. These banks, consequently, are more likely to experience an increase in troubled assets and a reduction in credit supply. Further analysis offers evidence of the "flight to headquarters" effect in credit allocation wherein more affected banks cut lending by a greater amount in markets located farther from headquarters.
\end{abstract}

JEL Codes: G01, G21

Keywords: geopolitical shock, credit allocation, asset quality, flight to headquarters, difference-in-differences

\footnotetext{
${ }^{a}$ Corresponding author. School of Management, Swansea University, Fabian Way, Swansea, United Kingdom SA1 8EN; email: anhthodav@gmail.com

${ }^{\mathrm{b}}$ Professor in Finance, School of Management, Swansea University, Fabian Way, Swansea, United Kingdom SA1 8EN

${ }^{\mathrm{c}}$ Deputy Head of Research Unit, Monetary Policy and Economic Analysis Department, National Bank of Ukraine, Kyiv, Ukraine.

${ }^{\mathrm{d}}$ Lecturer, Faculty of Economics, National University of Ostroh Academy, Ostroh, Ukraine
}

We thank Magnus Jonsson and Yevhen Dubohryz for their valuable comments and suggestions. 


\section{INTRODUCTION}

Banking activity is directly linked to changes in a country's socio-economic conditions. For instance, banks tend to adjust credit allocation across markets in response to changes in loan demand following natural disasters (Berg and Schrader, 2012; Cortés and Strahan, 2017). In addition, financial shocks to the banking sector often cause funding shortfalls and thus negatively affect banks' ability to lend after the shock (De Haas and Lelyveld, 2014). However, little is known about the link between banks' activities and pure exogenous shocks, which have direct influence on banks' balance sheets. ${ }^{1} \mathrm{How}$ are banks affected by fixed asset losses caused by the shock like a military conflict? How do banks adjust operations after being forced to withdraw from a market? In this paper, we aim to answer those questions, using the geopolitical conflict between Ukraine and Russia started in 2014 as the exogenous shock.

We are motivated by two recent developments in Ukraine. First, the Ukrainian banking sector has been severely affected by the annexation of Crimea and the armed conflict in the Donetsk and Luhansk oblasts (regions), which began in Q1 2014. Bank infrastructure has been destroyed by the military activities in the areas controlled by pro-Russian rebels, and banks are unable to collect loans issued in those regions prior to the conflict. That damage led Ukrainian banks to suspend operations, close branches, and freeze ATM and credit cards in those regions. Given the significance of the Donetsk and Luhansk oblasts to Ukraine's economy, it is important to understand how the loss of the eastern markets affects banks' activities in the rest of Ukraine.

Second, as part of the banking reform initiative launched in 2014, the concentration within Ukraine's banking sector has improved, with a sharp decrease in the number of insolvent banks and a steady increase in average assets (Figure 1). In addition, Ukrainian banks are also centralizing decision-making processes, with the increasingly important role of bank head offices in credit allocation. This raises a concern about the determinants of allocation decisions by those head offices in response to changes in the banking sector. This concern is even more important given the unrest in the east as banks must consider conflict-related uncertainty when making a loan decision.

We aim to address those concerns by using a unique and confidential dataset that contains (1) balance sheet and income statement data at the bank level, (2) data on loans at the bank-market level, and (3) detailed information on branch location. These data allow us to investigate whether banks' asset risk and lending activities after Q1 2014 are linked to their operations in the conflict areas as of Q1 2014. We also document whether the negative effect of the conflict to the eastern markets is transmitted to other markets through banks' diversified networks and to what extent the spillover effect

\footnotetext{
${ }^{1}$ This type of shocks is treated as geopolitical shocks because they materially affect the economy, the political situation, and society.
} 
could be mitigated. Additionally, we are interested in examining how the head offices of the more exposed banks distribute credit across markets during the post-conflict period.

Our key findings are summarized below. First, a bank's operations in eastern Ukraine before the conflict determine that bank's exposure to the conflict's aftermath. Banks that issued more loans in Donetsk and Luhansk regions are more likely to be affected by the conflict (conflict-exposed banks hereafter). Consequently, after Q1 2014, the more affected banks accumulate the non-performing loans (NPL) faster than peer banks. Furthermore, the more exposed banks have also faced a greater decrease in their rate of loan growth. That negative effect on loan is less severe among banks whose headquarters are located further away from the conflict areas. Second, we observe the shock to banks in Donetsk and Luhansk is transmitted to other markets, as branches of more affected banks also face higher risk in those markets. However, the further the markets are from the east, the less significant the effect is. In other words, there is evidence for the contagion of the geographical shock but this spillover fades with longer distance from the markets to conflict. We also note a variation in the shock exposure within a bank's network: asset quality problems are exacerbated the closer a bank branch is located to the conflict. Third, loan allocation differs with distance to a bank's head office. After the onset of the conflict, banks, especially those issuing more loans in conflict areas as of Q1 2014, are more likely to reduce lending in regions farther from their headquarters.

Our study contributes to several strands of literature. The first strand focuses on the transmission of shock in the banking sector. Many studies have documented that global banks can transmit a shock from one country to another (e.g., Cetorelli and Goldberg, 2011; Peek and Rosengren, 1997; Haas and Lelyveld, 2014). The broad finding is that when international banks are exposed to a negative shock, they tend to reduce cross-border lending regardless of the origin of the shock. For instance, Van Rijckeghem and Weder (2003) observe a decrease in capital flows in third countries following global banks' exposure to crises in Mexico and Asia. Similarly, Schnabl (2012) finds after Russia's default in 1998, international banks reduced interbank lending to Peruvian banks. Consequently, Peruvian banks reduced domestic credit supply.

Other studies have documented the effect of funding or liquidity shocks to banks on the real economy (e.g., Almeida et al., 2017; Chodorow-Reich, 2013, Di Maggio and Kermani, 2017) or on loan creation (Berrospide et al., 2016; Cortés and Strahan, 2017; Gilje et al., 2016). Using the oil and gas shale discoveries in the US in 2003 as a positive shock to banks' liquidity, Gilje et al. (2016) show that US banks with a higher number of branches tend to expand mortgage lending in other markets. By contrast, if a shock has a negative effect on bank funding, banks are more likely to reduce lending. For instance, the housing market collapse in 2007-2009 led multimarket banks to reduce local mortgage lending in response to high delinquency rates in other markets (Berrospide et al., 2016). We add to this literature by providing evidence for the impact of a shock to banks' assets on banks' activities. In particular, asset losses caused by a geopolitical conflict have a 
negative influence on the availability of bank credit and a bank's asset risk. Furthermore, we document that the negative effects of the shock may be lower in areas farther from the source of the shock.

Motivated by the first strand, the second strand of literature focuses on the "flight to home" effect, or the "home bias" in capital allocation. In a time of distress, banks continue lending in their home countries while tightening credit supply to foreign borrowers (e.g., Giannetti and Laeven, 2012a). This effect is observed clearly during the 2007-2009 financial crisis when international banks substantially reduced intra-group lending to their foreign affiliates, who, in turn, cut loan creation in their markets (Cetorelli and Goldberg, 2011, 2012). Moreover, the credit allocation in favor of home countries is more pronounced when non-deposit funding accounts for a large part of banks' liabilities or when banks are more exposed to liquidity shocks (Giannetti and Laeven, 2012 b). Several causes for the "flight to home" effect have been suggested. The first is related to informational and agency costs that increase with distance from borrowers to lenders (Ahearne et al., 2004; Portes and Rey, 2005). As information on the creditworthiness of borrowers tends to be "soft", information is more likely to be gathered at local branches or local affiliates. However, soft information cannot be easily transmitted, resulting in higher costs of communication or distorted information if the local branches (subsidiaries) are more distant from the head offices or parent banks (De Haas and Van Lelyveld, 2010). For this reason, the head offices (parent banks) have incentives to constrain lending in their more distant branches. The "home bias" is also highly related to similarity, indicated by common language or geographical distance between the home and host countries (Chan et al., 2005; Huberman, 2001).

Our results are closest to the work of De Haas and Van Horen (2012), who find that in reducing lending to foreign borrowers, banks treat different borrowers differently. Banks tend to cut credit supply by less in countries that are closer to their home countries. Similarly, we find a "flight to headquarters" effect within a bank's network, in which the reduction in lending is more severe in markets located farther from a bank's head office. This paper improves the methodology used by De Haas and Van Horen (2012) to control for difference in lending behavior before and after the shock, as well the difference in behavior between more affected and less affected banks. Thus, we show the "home bias" is not isolated from the degree of a bank's exposure to the negative shock.

The rest of this paper is organized as follows. Section 2 provides facts about the 2014 geopolitical conflict between Ukraine and Russia. In Section 3, we describe our identification strategy and the dataset. Section 4 discusses the empirical results. Section 5 concludes and offers the implications of our findings. 


\section{THE GEOPOLITICAL CONFLICT BETWEEN UKRAINE AND RUSSIA}

The geopolitical conflict between Ukraine and Russia started in March 2014 when Russia annexed sovereign Ukrainian territory, the Crimean Peninsula. Following the annexation, pro-Russian protests took place in the Donetsk and Luhansk oblasts and escalated into an armed confrontation. As of November 2017, Russia continues to illegally occupy Ukraine's Autonomous Republic of Crimea, the city of Sevastopol, and areas of Donetsk and Luhansk oblasts (Ministry of Foreign Affairs, Ukraine).

Donetsk and Luhansk oblasts are among the largest and most economically important in Ukraine. As of 2014, the Donetsk and Luhansk oblasts had populations of over four million and two million, respectively. The oblasts combined for $16 \%$ of Ukraine's GDP. The Donbas region (the broader Donetsk and Luhansk area) is Ukraine's industrial heartland, the core of the energy, coal mining, chemicals, construction materials, and heavy engineering sectors. The conflict with Russia started in 2014 has caused severe damage to the economy of these regions. Highways, railways, airports, and other transport infrastructure have been destroyed. Key industrial facilities in the Donbas have been disassembled and transported to Russian territory. Alongside the damage to the overall economy, the banking sector has also been affected. Ukrainian banks face substantial losses as loans issued in Crimea and the Donbas have gone unpaid. Per Regulation No. 260 issued by the National Bank of Ukraine (NBU) in 2014, all Ukrainian banks suspended operations in Crimea and Donetsk and Luhansk oblasts.

The abovementioned facts raise questions related to the impact of the conflict on the banking sector. The first being whether and to what degree the losses of fixed assets and unpaid loans affect banks' asset quality. Second, given the uncertainty about the future of the conflict, whether banks should adjust lending activity to account for the uncertainty.

\section{DATA AND EMPIRICAL SPECIFICATION}

\subsection{Identification strategy}

\subsubsection{Effects of a geopolitical shock on banks'asset quality and loan growth}

We argue that banks' operation after the conflict is closely related to their activities in the affected regions prior to the conflict. Banks that had more loans outstanding in Donetsk and Luhansk oblasts as of Q1 2014 are more likely to be exposed to the conflict and thus face a deterioration of asset quality and a greater reduction in loan growth afterwards. To test this hypothesis, we adopt the difference-in-differences approach with the continuous treatment as follows: 


$$
\text { Dependent }_{b, t}=\beta_{0}+\beta_{1} \text { Loan share }_{b, 2014 \mathrm{Q1}} \times \text { Conflict }+X_{b, t-1} \beta_{2}+\epsilon_{b}+u_{t}+\varepsilon_{b, t} \text {, }
$$

where $b$ refers to a bank and $t$ refers to a quarter. Dependent variables are either (1) $N P L$ which is the ratio of non-performing loans to total loans or (2) Loan growth which is the difference in the natural logarithm of the amount of loans issued by a bank. We further investigate the effect of the shock on different types of loans: corporate and personal. Loan share is the share of loans granted by a bank in Luhansk and Donetsk as of Q1 2014. Since the overdue on loans to firms or individuals may only depend on the share of each loan type, we also measure Loan share separately for corporate loans and personal loans. Conflict is a dummy that equals 1 for the quarters after Q1 2014 and 0 for the quarters before Q1 2014. ${ }^{2}$ In addition, the impact of conflict exposure on loan growth could be mitigated by the distance from the head offices to the conflict area. We implement this argument by adding a triple interaction term among Loan share, Conflict and Distance from headquarters to conflict in the regression with Loan growth as the dependent variable. Distance from headquarters to conflict is the natural logarithm of the geodesic distance from the city that hosts a bank's head office to the city of Donetsk.

Vector $X$ includes a set of bank-specific variables that can affect banks' asset quality. We calculate Wholesale funding (the ratio of funding from non-bank financial institutions to total funding), Size (the natural logarithm of total assets), Equity (total equity divided by total assets), Deposits/Assets (total deposits divided by total assets), Provisions (loan loss provisions divided by total assets), and Branches (the natural logarithm of total bank branches). We also include time $\left(u_{t}\right)$ and bank $\left(\epsilon_{b}\right)$ fixed effects. All bankspecific variables are winsorized at the 1st and 99th percentile of their distributions. Model (1) is estimated for four quarters before and after Q1 2014.

The main assumption of this identification strategy is the parallel trend of the treatment between the control and treatment groups in the pre-conflict period. More specifically, before Q1 2014, banks' activities in Donetsk and Luhansk were not the main determinant of the quality of banks' assets. Following previous studies (e.g., Autor 2003), we augment the n "leads" and q "lags" of the treatment into model (1) to test the validity of this parallel trend assumption.

$$
\text { Dependent }_{b, t}=\beta_{0}+\beta_{1} \sum_{j=-n}^{q} \theta_{j} \text { Conflict }_{2014 Q 1+j} \times \text { Loan share }_{b, t}+\mathrm{X}_{b, t-1} \beta_{2}+\epsilon_{b}+u_{t}+\varepsilon_{b, t} \text {, }
$$

where Loan share equals the share of loans in Luhansk and Donetsk in each quarter before Q1 2014, and equals the share as of Q1 2014 for all quarters starting from Q1 2014. Pre-conflict and post-conflict effects of the treatment on banks' asset risk are indicated

\footnotetext{
${ }^{2}$ We use robust standard errors throughout our analysis. Since Loan share does not vary across markets for a given bank-market, we also construct standard errors by clustering by bank in all regressions as robustness checks and get consistent results.
} 
by the variable(s) Conflict ${ }_{2014 Q 1+j}$. From Q2 2013 to Q4 2014, these binary variables equal one only in the relevant quarter, and equal one in each quarter starting from Q1 2015. We expect all coefficients on the treatment during the pre-crisis period to equal zero $\left(\theta_{j}=0, \forall_{j}<0\right)$. Vector $\mathrm{X}$ is defined as it is in model (1).

\subsubsection{Contagion of shock and post-conflict lending behaviour}

Figure 2 shows the map of Ukraine, where we group Ukraine's oblasts by distance to the occupied and pro-Russian regions. The oblasts that share borders with Luhansk, Donetsk, or Crimea are grouped into Zone 1; oblasts that share borders Zone 1 oblasts, plus Odesa, are grouped into Zone 2; all other oblasts are grouped into Zone 3. Because a market's distance to the conflict zone can determine the extent to which that market is affected by the shock in the east, we then estimate the effect of model (1) on these three sub-groups. We expect to see a transmission of the shock in the east to other parts of Ukraine and expect the spillover effect to fade further from the conflict. The degree of conflict exposure of a bank branches in each zone is estimated by the ratio of non-performing loans in that zone to the bank's total loans. Other variables are defined exactly as in model (1).

To further investigate the transmission of the shock from the east to each individual market and banks' lending behaviour after the shock, we employ the following model:

$$
\begin{aligned}
& \text { Dependent }_{b, m, t}=\beta_{0}+\beta_{1} \text { Loan share }_{b, 2014 \mathrm{Q} 1} \times \text { Distance } \times \text { Conflict }+\beta_{2} \text { Loan share }_{b, 2014 \mathrm{Q} 1} \\
& \times \text { Conflict }+B M_{b, m, t-1} \beta_{3}+\beta_{4} \text { Share of branches of the market } \text { matt-1 }+\epsilon_{b}+\theta_{m, t}+\varepsilon_{b, m, t} \text {, }
\end{aligned}
$$

where $b$ indexes banks, $m$ indexes markets, and $t$ indexes quarters. Dependent variables are either NPL or Loan growth measured at the bank-market level. Thus, in each quarter, these ratios are identical for each bank-market pair. In the regression with $N P L$ as the dependent variable, Distance is Distance to conflict which is the natural logarithm of the geodesic distance from an oblast's capital to the city of Donetsk. ${ }^{3}$ In the regression with Loan growth as the dependent variable, Distance is Distance to headquarters which is the natural logarithm of the geodesic distance from a market to the bank's head office. We argue that the more affected banks that face higher asset risk than less affected peers may reduce lending in the markets farther away from its head office. The closer a market is to a bank's head office, the easier it is to control the quality of new loans issued in that market, thus reducing problems related to troubled assets.

$B M$ is a vector of bank-market specific variables including (1); Share of loans to firms (ratio of loans issued to corporate borrowers by a bank in a market to its total

\footnotetext{
${ }^{3}$ This is exceptional from Luhansk. The geodesic distance between Luhansk and Donetsk oblasts are taken as zero. The empirical results are robust to the use of real distance between these two regions.
} 
loans); (2) Share of loans to individuals (ratio of loans issued to individual borrowers by a bank in a market to its total loans); (3) Share of branches in the market (ratio of a bank's number of branches in a market to the bank's total number of branches), and (4) Number of other bank branches (natural logarithm of the number of competitor bank branches in a market). We include Share of branches of the market, which is the ratio of the number of branches of all banks in a market to the total number of all banks' branches, to control for market-specific characteristics. We also include (1) $\theta_{m, t}$ to control for the market-time fixed effects and (2) $\epsilon_{b}$ to control for bank fixed effects.

Like the underlying assumption in model (1), here we assume that before Q1 2014, the link between a bank's activities in Luhansk and Donetsk and the quality of its assets in other markets was not affected by the distance. Again, a similar approach is used to test that assumption.

$$
\begin{aligned}
& \text { Dependent } t_{b, m, t}=\beta_{0}+\beta_{1} \sum_{j=-n}^{q} \theta_{j} \text { Conflict }_{2014 Q 1+j} \times \text { Loan share }_{b, t} \times \text { Distance } \\
& +M B_{b, m, t-1} \beta_{2}+\beta_{3} \text { Share of branches of the market } \text { matt-1 }_{b}+\epsilon_{b, t}+\varepsilon_{b, m, t} .
\end{aligned}
$$

The pre- and post-conflict effects of the interaction between Loan share and Distance are indicated by Conflict $_{2014 Q 1+j}$, defined as in model (2). Distance is Distance to conflict or Distance to headquarters in the regressions with NPL or Loan growth as the dependent variable, respectively. The control variables are similar to model (3).

\subsection{Data sources and sample}

We employ a unique and confidential dataset of quarterly information for Q1 2008 to Q4 2016. The data combine three datasets: (1) bank income statement and balance sheet data, (2) balance sheet data at the market level, and (3) bank branch locations. These data allow us to measure the exposure of banks to the geopolitical conflict in eastern Ukraine and to observe banks' asset quality and lending behaviour in each geography in the post-conflict period.

The cleaning process is as follows. As the conflict is between Ukraine and Russia, Russian-owned banks may be affected differently. Thus, we exclude Russian-owned banks from the sample. Insolvent or liquidated banks are also excluded. At the bank level, we remove data on banks whose head offices are based in Crimea. After cleaning, our data consist of 135 banks with 4,065 observations, allowing for the entry and exit of banks from the dataset. In the regressions with loan growth as the dependent variable, we further exclude banks whose head offices are in Donetsk and Luhansk. ${ }^{4}$

Table 1 presents the descriptive statistics for bank-level data. On average, the

\footnotetext{
${ }^{4}$ In total, eight banks with 249 observations are excluded. Data on loan growth and non-performing loans are also adjusted for loans and bad loans in Donetsk and Luhansk. Our results are quantitatively similar if we include those data in the estimation sample.
} 
amount of loans issued to corporate borrowers is slightly higher than those issued to individuals. However, the NPL ratio for corporate loans is about two times higher than for personal loans. In terms of lending activities in the east, the total loans issued in Luhansk and Donetsk as of Q1 2014 account for 7.6\% of all loans (5.5\% to corporate borrowers and $1.9 \%$ to individuals). Among other bank characteristics, loan loss provisions make up a significant proportion of total assets (34.8\%), a sign of a fragile banking sector. Banks are less likely to raise funds from non-bank financial institutions, with the average wholesale funding ratio at $4.9 \%$. On average, total deposits and equity capital account for $8.0 \%$ and $21.1 \%$ of total assets, respectively. Despite the ongoing clean-up of the banking sector, Ukrainian bank branch networks are still large, averaging 40.

At the bank-market level, we exclude the balance sheet data of bank branches in Crimea, Luhansk, and Donetsk. Our final sample contains 1,424 bank-market pairs with 33,748 observations. In the estimation with Loan growth as the dependent variable, we further exclude banks whose head offices are located in the conflict areas. ${ }^{5}$ The summary statistics for the bank-market data are presented in Table 2 . In general, the markets are competitive with a large number of bank branches. However, the physical presence of banks varies across different markets, suggesting that certain banks dominate certain markets. A high level of troubled assets is again observed, with an NPL ratio of $66.1 \%$. Most banks have their head offices in Kyiv, with an average distance to other markets of about $130 \mathrm{~km}$. On average, the distance from head offices to the conflict is about $500 \mathrm{~km}$.

Figure 3 provides an insight into the link between loan share in Donetsk and Luhansk as of Q1 2014 and banks' subsequent asset quality and credit supply. The chart below compares the NPL ratio and loan growth of two groups, including the group of banks whose loan share in the conflict areas is at least 5\% (high share group) and the group of banks whose share is below 5\% (low share group). Prior to the conflict, the NPL ratios of the two groups were nearly identical and the NPL ratios of each group remained consistent from Q2 2013 to Q4 2013. In the quarters after Q1 2014, the NPL ratios of both groups increased steadily. Moreover, the NPL ratio of the high share group was significantly higher than that of the low share group. Loan creation declined or both groups of banks after Q1 2014. However, the lending decline of the high share group is substantially greater than the low share group, especially in the 1st quarter after the conflict started. More specifically, in Q2 2014, the high share group saw loans decrease $10 \%$, much faster than the low share group's $2 \%$ decline. This suggests the variation in banks' lending activities in Donetsk and Luhansk as of Q1 2014 may be related to the subsequent degree of exposure to the conflict.

\footnotetext{
${ }^{5}$ After exclusions, the estimation sample consists of 1,361 bank-market pairs with 32,609 observations. Our results are quantitatively similar if those data are included.
} 


\section{RESUlTS}

\subsection{Which banks are more exposed to the geopolitical conflict?}

Figures 4 and 5 show the pattern of the coefficient $\theta_{j}$ in models (2) and (4), respectively. Before the conflict, the coefficients on Loan share are near zero. By contrast, the coefficients are positive from the start of the conflict in Figure 4 but negative after Q1 2014 in Figure 5. In other words, the parallel trend assumptions are valid.

The results for model (1) are presented in Table 3. Banks that had a higher intensity of lending in Luhansk and Donetsk as of Q1 2014 are more likely to experience a higher level of loss-generating assets afterwards. More specifically, an increase of one standard deviation in the share of total loans issued in Luhansk and Donetsk as of Q1 2014 leads to a $0.016 \%$ increase in the NPL ratio in subsequent quarters. Similarly, an increase of one standard deviation in the share of loans issued to firms in Luhansk and Donetsk as of Q1 2014 leads to an increase of $0.017 \%$ in the NPL ratio of corporate loans. Because personal loans only account for a small proportion of all bank loans in Luhansk and Donetsk, its effect on the banks' amount overdue on individual loans is also weaker. The NPL ratio for personal loans increases by only $0.005 \%$ with an increase of one standard deviation in the share of individual loans issued in the conflict areas as of Q1 2014.

Table 4 shows the results for model (3). We find that more exposed banks are more likely to reduce their loan issuance. This negative effect is both statistically and economically significant. An increase of one standard deviation in the share of total loans issued in the conflict areas as of Q1 2014 results in a reduction of $1.46 \%, 1.64 \%$ and $1.24 \%$ in the loan growth rate of total loans, corporate loans, and personal loans, respectively. However, the negative impact of the conflict on loan supply decreases with the distance from a bank's head office to the conflict. In other words, among the more exposed banks, the shock has a lower impact on those banks whose head offices are farther away from Donetsk.

Regarding other bank characteristics, we find that a reliance on non-core funding is positively related to asset quality. This finding supports the argument that wholesale funding has a positive effect on bank efficiency as it allows wholesale financiers to monitor banks better (e.g., Calomiris, 1999; Huang and Ratnovski, 2011). Consistent with Ghosh (2015), we also observe a strong relationship between poor credit quality (as indicated by loan loss provisions) and a higher NPL ratio. A larger branch network is positively related to loan growth while lowering NPL, which points to the benefits of geographic diversification.

The results offer an in-depth understanding about the degree of banks' exposure to a shock. More specifically, a bank is affected more severely if its activities in the shock areas account for a large proportion of overall operations. Additionally, the shock to a bank's assets leads to a decrease in asset quality. In other words, during the onset of 
the shock, more affected banks face higher risks than less affected counterparts. Thus, more affected banks might be incented to issue higher quality loans instead of a greater quantity of loans in anticipation of further losses, resulting in a reduction in lending. However, we do not rule out the possibility that the decline in credit supply is caused by the funding shortage as widely documented in literature (e.g., Berrospide et al., 2016; Giannetti and Laeven, 2012a; Haas and Lelyveld, 2014).

\subsection{How is the shock transmitted?}

Table 5 shows the results for the transmission of the conflict in the east to other market zones. On one hand, we do not find evidence of the transmission of the negative effect on the total NPL ratio and corporate NPL ratio. On the other hand, banks with more personal loans outstanding in Donetsk and Luhansk as of Q1 2014 do face higher NPL ratios for personal loans in Zone 1 and subsequently in Zone 2. This negative spillover effect fades from Zone 1 to Zone 2. An increase of ten standard deviations in the share of personal loans in the conflict regions leads to an increase of $0.013 \%$ and $0.007 \%$ in the NPL ratio for personal loans in Zones 1 and 2, respectively. By comparison, the magnitude of the spillover from the conflict to neighboring markets (Zone 1) is about two times higher than that to Zone 2 markets. The impact is washed out in Zone 3 . This suggests the conflict is less likely to affect more distant markets.

Figure 6 presents the coefficients for the parallel trend assumption test in model (6). Before the conflict, the coefficients on the interaction between Distance to conflict and Share of loans are near zero. By contrast, during the 2nd and 3rd quarters after the conflict, the coefficients are significantly below zero. In other words, after Q1 2014, the impact of loans outstanding in Donetsk and Luhansk on risk profile changes with distance from a market to the shock areas. This confirms the parallel trend assumption is valid. Table 6 shows the results of the empirical test for this argument. We find consistent results for the impact of the share of loans in Donetsk and Luhansk as of Q1 2014 on the NPL ratio in the subsequent quarters. We also observe a negative and significant coefficient on the interaction term between Loan share, Distance to conflict, and Conflict. In other words, the geographical distance from a market to the conflict can mitigate the negative effect of the conflict on the stability of a bank in that market.

The marginal effects of Loan share in Luhansk and Donetsk as of Q1 2014 and Distance to conflict on the NPL ratio are shown graphically in Figure 7. Comparing asset quality of bank branches located in the markets which are $100 \mathrm{~km}$ away from the conflict, the NPL ratio increases with banks' higher share in Luhansk and Donetsk as of Q1 2014 when holding all other characteristics equal. The most affected banks are those with more than a 50\% share of loans in the conflict areas. However, the degree of the impact varies across these banks' markets as the NPL ratio indeed declines as the distance to the conflict increases. More specifically, when we compare the effect of Loan 
share on asset quality of branches in markets located $100 \mathrm{~km}$ and $300 \mathrm{~km}$ away, the $N P L$ ratio of the farther group is about 2 times higher than the ratio of the closer group (Figure 8). Interestingly, the greatest distances of $500 \mathrm{~km}$ and more do not only absorb the negative effect of the conflict but also see a reduction of the NPL ratio at branches in those markets.

Our results can be explained using the remoteness concept widely used in trade literature, which suggests that a country chooses its trade partners based on both geographic distance and remoteness (e.g., Nitsch 2000, Anderson and Van Wincoop 2003). This means the probability of trade contracts between two countries increases the closer they are located geographically. However, holding the bilateral distance constant, a country pair tends to have more bilateral trades if they have few neighbours nearby. Building on this principal and based on the geographical characteristics, we argue that within a bank's network, branches in Donetsk and Luhansk tend to be connected with other branches in near-by markets, e.g. through activities in internal capital markets. By contrast, the connectedness decreases with branches located farther away, in Ukraine's case, to the west. Consequently, the negative shock to a bank's branches in the east is likely to spread to the closest neighbours and less likely to be transmitted to that bank's branches in more distant markets.

\subsection{Lending behavior after the shock}

We have found that banks that are more exposed to the conflict in the east tended to reduce lending after the start of the shock. That effect also faded the farther a bank's head office was from the conflict. Next, we look at whether more exposed banks supply credit disproportionally in markets located farther from its head office.

The results for the parallel assumption test are shown in Figure 9. Again, we note the coefficients on the interaction term between Loan share, Distance to Headquarters, and Conflict are near zero before Q1 2014. Immediately after the conflict, the coefficients are significantly below zero, satisfying the validity of the assumption. The results for model (7) are presented in Table 7. We find that after the conflict, the banks more exposed to the conflict have incentives to cut loan creation in markets farther from its head office, while the reduction in loan creation is lower closer to the head office.

Figure 10 presents the marginal effects of Loan share and Distance to Headquarters on loan growth. Branches belonging to less affected banks and located in the same markets as the bank's head office experienced the smallest decrease in the rate of loan growth. The reduction of credit supply increases with a higher Distance to Headquarters or/and higher Loan share. For example, among branches located $100 \mathrm{~km}$ from their head office, the branches of banks with a 10\% Loan share face a greater decrease in loans than do branches with a 40\% Loan share. In addition, among banks with $60 \%$ of loans issued in Luhansk and Donetsk as of Q1 2014, branches located $900 \mathrm{~km}$ away from the 
head offices have reduced lending most. To better understand how the link between conflict exposure and loan reduction is amplified by the distance between the branches and their head office, we perform the sensitivity test as shown in Figure 9. We observe that the decline in the rate of loan growth in the market located $100 \mathrm{~km}$ away from the head office is about $1 / 4$ of the decrease in loan growth of branches located $900 \mathrm{~km}$ away from their head office.

These findings support the "flight to headquarters" effect suggested by De Haas and Van Horen (2012). As argued earlier, more exposed banks tend to manage new loans better in anticipation of additional losses. One way to do so is to rebalance the loan portfolios in favor of markets located closer to the head office. This may be explained by several factors. First, greater distance between local branches and their head offices reflects higher monitoring costs and greater agency problems. That may result in lower efficiency and increased risks (Alessandrini et al., 2012; Berger and DeYoung, 2001; Deng and Elyasiani, 2008). Because more exposed banks already face a higher level of troubled assets than less exposed banks, the former may have an incentive to reallocate credit to branches located closer to their head office. That would ease loan management and monitoring, thus reducing loss-generating assets. Second, information on local borrowers, whether "soft" or "hard" information, is most likely collected at local branches (Agarwal and Hauswald, 2010; Alessandrini et al., 2008). Loan officers tend to rely on "soft" information in lending, which is not easily conveyed from the local office to the head office, the center of decision-making. As a result, banks are more willing to lend to borrowers located closer to the head office as banks are better informed about the borrowers. In other words, greater distance between the head office and the local market, as well as the centralized decision-making process, leads to a significant reduction in credit supply in more distant markets. Third, even if lending decisions are made solely based on "hard" information, physical distance still matters as greater distances decrease the probability of default recovery (Mian, 2006). Because the more exposed banks already face substantial losses from the conflict, re-allocating loans closer to the headquarters is a means to prevent greater losses.

\subsection{Robustness checks}

Following Brown et al. (2017), we perform cross-sectional estimations repeatedly for the following model which is estimated for individual quarters after Q1 2014.

\footnotetext{
Dependent $_{b, m, t}=\beta_{0}+\beta_{1}$ Loan share $_{b, 2014 \mathrm{Q1}} \times$ Distance $+\beta_{2}$ Loans $_{b, 2014 \mathrm{Q1}}+X_{b, m, t-1} \beta_{3}+$ $M_{m, t-1} \beta_{4}+\epsilon_{b}+\theta_{m, t}+\varepsilon_{b, m, t}$.

Table 8 shows the coefficients from the repeated estimations. As expected, the share of loans issued in Luhansk and Donetsk as of Q1 2014 is positively related to 
the NPL ratio in other markets in each quarter after the conflict. The effect increases gradually over time and is strongest in the 3rd quarter after the shock. After that, the negative impact of a bank's conflict exposures on asset quality of its branches in other markets fades. However, this effect diminishes with greater distance from a market to the conflict areas. We also note the decrease in lending experienced by the more exposed banks. As documented previously, Q3 2014 is when loan growth and asset quality were most affected. In addition, the decrease in lending among the more exposed banks is amplified by greater distance between branches and their head offices. In general, these results are consistent with our main findings.

\section{CONCLUSION}

In this paper, we investigate the impact of the 2014 geopolitical conflict in eastern Ukraine on banks' activities and the transmission of this shock to banks' operations in other parts of Ukraine. Like the impact of financial shocks documented in the current literature, a geopolitical shock can affect asset quality and lending volume. Specifically, we first find that a bank's exposure to the conflict is linked to its operations in the conflict areas as of the time of the shock. Banks with more outstanding loans in the shockoriginating regions as of Q1 2014 are more likely to be affected by the negative shock afterwards. As a result, in the post-conflict period, the more exposed banks experience a higher level of troubled assets and a deeper reduction in credit supply than their less exposed peers.

Second, we investigate the spillover of the shock from the east to other markets. While the negative shock to the banking sector in the conflict regions is transmitted to other parts of the country, the effect is lessened farther from the conflict zone. There is also evidence of the transmission of the shock through a bank's network. This supports the argument that interconnectedness and geographical diversification are channels for the transmission of the shock (e.g., Berrospide et al., 2016; Iyer and Peydro, 2011). However, the amplification of the conflict is mitigated by the distance from the markets to the conflict areas. For example, for a bank that is severely affected by the shock, its branches located in distant markets experience a lower NPL ratio and higher loan growth than branches located near the conflict.

Third, we document a difference in lending supply across the markets of operation of the more affected banks and reiterate the "flight to headquarters" effects. Although the conflict-exposed banks tend to cut lending more than less exposed peers, the magnitude of the lending reduction differs across markets. Banks are likely to scale back lending by less in markets located near their head offices. We argue that issuing loans to nearer markets simplifies control and monitoring over borrowers for the head office, thus reducing risks. 


\section{REFERENCES}

Acharya V. V., Mora N. (2015). A crisis of banks as liquidity providers. Journal of Finance, Vol. 1, pp. 1-43.

Agarwal, S., Hauswald, R. (2010). Distance and private information in lending. Review of Financial Studies, Vol. 7, pp. 2757-2788.

Ahearne A.G., Griever W.L., Warnock F.E. (2004). Information costs and home bias: an analysis of US holdings of foreign equities. Journal of International Economics, Vol. 2, pp. 313-336.

Alessandrini P., Croci M., Zazzaro A. (2012). The geography of banking power: role of function distance. PSL Quarterly Review Vol. 58, No. 235, pp. 129-167.

Alessandrini P., Presbitero A.F., Zazzaro A. (2008). Banks, distances and firms' financing constraints. Review of Finance, Vol. 13, No. 2, pp. 261-307.

Almeida H., Cunha I., Ferreira M.A., Restrepo F. (2017). The real effects of credit ratings: The sovereign ceiling channel. Journal of Finance, Vol. 72, No. 1, pp. 249-290.

Anderson J.E., Van Wincoop E. (2003). Gravity with gravitas: A solution to the border puzzle. The American Economic Review, Vol. 93, No. 1, pp. 170-192.

Autor D.H. (2003). Outsourcing at will: The contribution of unjust dismissal doctrine to the growth of employment outsourcing. Journal of Labor Economics, Vol. 21, No. 1, pp. 1-42.

Barisitz S., Fungáčová Z. (2015). Ukraine: struggling banking sector amid substantial uncertainty. Financial Stability Report, No. 29, pp. 72-92.

Berg G., Schrader J. (2012). Access to credit, natural disasters, and relationship lending. Journal of Financial Intermediation, Vol. 21, No. 4, pp. 549-568.

Berger A.N., DeYoung R. (2001). The effects of geographic expansion on bank efficiency. Journal of Financial Services Research, Vol. 19, No. 1-2, pp. 163-184.

Berrospide J.M., Black L.K., Keeton W.R. (2016). The Cross-Market Spillover of Economic Shocks through Multimarket Banks. Journal of Money, Credit and Banking, Vol. 48, No. 5, pp. 957-988.

Calomiris C.W. (1999). Building an incentive-compatible safety net. Journal of Banking \& Finance, Vol. 23, No. 10, pp. 1499-1519.

Cetorelli, N., Goldberg L.S. (2011). Global banks and international shock transmission: Evidence from the crisis. IMF Economic Review, Vol. 59, No. 1, pp. 41-76.

Cetorelli N., Goldberg L.S. (2012). Follow the money: Quantifying domestic effects of foreign bank shocks in the great recession. American Economic Review, Vol. 102, No. 3, pp. 213-218. 
Chan K., Covrig V., Ng L. (2005). What determines the domestic bias and foreign bias? Evidence from mutual fund equity allocations worldwide. Journal of Finance, Vol. 60, No. 3, pp. 1495-1534.

Chodorow-Reich, G. (2013). The employment effects of credit market disruptions: Firmlevel evidence from the 2008-9 financial crisis. Quarterly Journal of Economics, Vol. 129, No. 1, pp. 1-59.

Cortés K.R., Strahan P.E. (2017). Tracing out capital flows: How financially integrated banks respond to natural disasters. Journal of Financial Economics, Vol. 125, No. 1, pp. 182-199.

De Haas R., Lelyveld I. (2014). Multinational banks and the global financial crisis: Weathering the perfect storm? Journal of Money, Credit and Banking, Vol. 46, No. 1, pp. 333-364.

De Haas R., Van Horen N. (2012). Running for the exit? International bank lending during a financial crisis. Review of Financial Studies, Vol. 26, No. 1, pp. 244-285.

De Haas R., Van Lelyveld I. (2010). Internal capital markets and lending by multinational bank subsidiaries. Journal of Financial Intermediation, Vol. 19, No. 1, pp. 1-25.

Deng S.E., Elyasiani E. (2008). Geographic diversification, bank holding company value, and risk. Journal of Money, Credit and Banking, Vol. 6, No. 6, pp. 1217-1238.

Di Maggio M., Kermani A. (2017). Credit-induced boom and bust. Review of Financial Studies, Vol. 30, No. 11, pp. 3711-3758.

Ghosh A. (2015). Banking-industry specific and regional economic determinants of nonperforming loans: Evidence from US states. Journal of Financial Stability, Vol. 20, No. C, pp. 93-104.

Giannetti M., Laeven L. (2012a). Flight home, flight abroad, and international credit cycles. The American Economic Review, Vol. 102, No. 3, pp. 219-224.

Giannetti M., Laeven L. (2012b). The flight home effect: Evidence from the syndicated loan market during financial crises. Journal of Financial Economics, Vol. 104, No. 1, pp. 23-43.

Gilje E.P., Loutskina E., Strahan P.E. (2016). Exporting liquidity: Branch banking and financial integration. Journal of Finance Vol. 71, No. 3, pp. 1159-1184.

Huang R., Ratnovski L. (2011). The dark side of bank wholesale funding. Journal of Financial Intermediation, Vol. 20, No. 2, pp. 248-263.

Huberman G. (2001). Familiarity breeds investment. Review of Financial Studies, Vol. 14, No. 3, pp. 659-680. 
Iyer R., Peydro J.L. (2011). Interbank contagion at work: Evidence from a natural experiment. Review of Financial Studies, Vol. 24, No. 4, pp. 1337-1377.

Mian A. (2006). Distance constraints: The limits of foreign lending in poor economies. Journal of Finance, Vol. 61, No. 3, pp. 1465-1505.

Nitsch V. (2000). National borders and international trade: evidence from the European Union. Canadian Journal of Economics/Revue Canadienne D'économique, Vol. 33, No. 4, pp. 1091-1105.

Peek J., Rosengren E.S. (1997). The international transmission of financial shocks: The case of Japan. American Economic Review, Vol. 87, No. 4, pp. 495-505.

Portes R., Rey H. (2005). The determinants of cross-border equity flows. Journal of international Economics, Vol. 65, No. 2, pp. 269-296.

Puri M., Rocholl J., Steffen S. (2011). Global retail lending in the aftermath of the US financial crisis: Distinguishing between supply and demand effects. Journal of Financial Economics, Vol. 100, No. 3, pp. 556-578.

Schnabl P. (2012). The international transmission of bank liquidity shocks: Evidence from an emerging market. Journal of Finance, Vol. 67, No. 3, pp. 897-932.

Van Rijckeghem C., Weder B. (2003). Spillovers through banking centers: a panel data analysis of bank flows. Journal of International Money and Finance, Vol. 22, No. 4, pp. 483-509. 


\section{TABLES}

Table 1. Descriptive statistics, bank-level data

\begin{tabular}{llll}
\hline & Mean & SD & Obs. \\
\hline & $(1)$ & $(2)$ & $(3)$ \\
\hline Bank asset quality & & & \\
\hline NPL (firms) & 0.049 & 0.070 & 3,960 \\
NPL (individuals) & 0.025 & 0.039 & 4,002 \\
NPL (total) & 0.073 & 0.088 & 4,038 \\
\hline Bank loans & & & \\
\hline Ln(loans to firms) & 13.201 & 2.026 & 3,799 \\
Ln(loans to individuals) & 11.362 & 2.468 & 3,800 \\
Ln(total loans) & 13.580 & 1.764 & 3,810 \\
\hline Bank activities in Luhansk and Donetsk as of Q1 2014 & & & \\
\hline Share of total loans in Donetsk and Luhansk & 0.076 & 0.203 & 4,132 \\
Share of loans issued to firms in Donetsk and Luhansk & 0.055 & 0.167 & 4,132 \\
Share of loans issued to individuals in Donetsk and Luhansk & 0.019 & 0.063 & 4,132 \\
\hline Other characteristics & & & \\
\hline Wholesale funding & 0.049 & 0.094 & 3,809 \\
Deposits/Assets & 0.080 & 0.127 & 4,059 \\
Provisions & 0.348 & 0.176 & 4,065 \\
Size & 14.258 & 1.675 & 4,065 \\
Branches & 3.612 & 1.820 & 4,026 \\
Equity/Assets & 0.211 & 0.177 & 4,065 \\
\hline
\end{tabular}

Notes: This table presents descriptive statistics for bank-level data. NPL (firms), NPL (individuals), NPL (total) are the ratios of nonperforming loans issued firms, to individuals, and total non-performing loans divided by total loans, respectively. $\operatorname{Ln}(\operatorname{loans}$ to firms), Ln(loans to individuals), and Ln(total loans) are the natural logarithms of loans issued to firms, to individuals, and total loans, respectively. Wholesale funding is the ratio of deposits from non-bank financial institutions to total funding from customers. Size is the natural logarithm of total assets. Equity is the ratio of total equity to total assets. Deposits/Assets is the ratio of total deposits to total assets. Provisions is the ratio of loan loss provisions to total assets. Branches is the natural logarithm of total bank branches. 
Table 2. Descriptive statistics, bank-market data

\begin{tabular}{|c|c|c|c|}
\hline & Mean & SD & Obs. \\
\hline & (1) & (2) & (3) \\
\hline \multicolumn{4}{|l|}{ Bank asset quality } \\
\hline NPL (firms) & 0.410 & 2.758 & 24,745 \\
\hline NPL (individuals) & 0.259 & 1.172 & 28,300 \\
\hline NPL (total) & 0.661 & 3.869 & 28,986 \\
\hline \multicolumn{4}{|l|}{ Bank loans } \\
\hline Ln(total loans) & 9.793 & 3.637 & 31,326 \\
\hline Ln(loans to firms) & 9.089 & 4.008 & 27,261 \\
\hline Ln(loans to individuals) & 8.707 & 3.488 & 30,772 \\
\hline \multicolumn{4}{|l|}{ Other bank-market characteristics } \\
\hline Number of other bank branches & 7.001 & 0.642 & 33,748 \\
\hline Number of branches & 1.749 & 1.418 & 33,748 \\
\hline Share of loans to firms & 0.093 & 0.473 & 27,878 \\
\hline Share of loans to individuals & 0.021 & 0.068 & 31,800 \\
\hline Distance to conflict & 6.143 & 0.597 & 33,748 \\
\hline Distance to headquarters & 4.832 & 2.036 & 32,609 \\
\hline Share of branches in the market & 0.018 & 0.044 & 33,748 \\
\hline Share of branches of the market & 0.092 & 0.175 & 33,748 \\
\hline
\end{tabular}

Notes: This table presents descriptive statistics for bank-market data. NPL (firms), NPL (individuals), NPL (total) are the ratios of nonperforming loans issued to firms, to individuals, and total non-performing loans divided by total loans, respectively. Ln(loans to firms), Ln(loans to individuals,) and Ln(total loans) are the natural logarithms of loans issued to firms, to individuals, and total loans, respectively. Distance to conflict is the natural logarithm of the geodesic distance from an oblast's capital to the city of Donetsk. Distance to headquarters is the natural logarithm of the geodesic distance from a market to the bank's head office. Share of loans to firms is the ratio of loans issued to firms by a bank in a market to that bank's total loans. Share of loans to individuals is the ratio of loans issued to individuals by a bank in a market to that bank's total loans. Number of branches is the natural logarithm of a bank's branches in a market. Share of branches in the market is the ratio of a bank's branches in a market to that bank's total branches. Number of other banks' branches is the natural logarithm of the number of competitor bank branches in a market. Share of branches of the market is the ratio of the number of all branches in a given market to the total number of bank branches. 
Table 3. Effects of the conflict on bank asset quality

\begin{tabular}{|c|c|c|c|}
\hline & $\begin{array}{l}\text { NPL } \\
\text { (total) }\end{array}$ & $\begin{array}{l}\text { NPL } \\
\text { (firms) }\end{array}$ & $\begin{array}{l}\text { NPL } \\
\text { (individuals) }\end{array}$ \\
\hline & (1) & $(2)$ & (3) \\
\hline \multirow[t]{2}{*}{ Share of total loans in Donetsk and Luhansk ${ }^{*}$ Conflict } & $0.081^{* *}$ & & \\
\hline & $(0.037)$ & & \\
\hline \multirow[t]{2}{*}{ Share of loans to firms in Donetsk and Luhansk *Conflict } & & $0.100^{* *}$ & \\
\hline & & $(0.049)$ & \\
\hline \multirow[t]{2}{*}{ Share of loans to individuals in Donetsk and Luhansk ${ }^{*}$ Conflict } & & & $0.086^{* * *}$ \\
\hline & & & $(0.032)$ \\
\hline \multirow[t]{2}{*}{ Wholesale funding } & $-0.082^{\star *}$ & $-0.083^{* *}$ & 0.001 \\
\hline & $(0.036)$ & $(0.040)$ & $(0.012)$ \\
\hline \multirow[t]{2}{*}{ Provisions } & $0.362^{* *}$ & $0.338^{* *}$ & -0.023 \\
\hline & $(0.148)$ & $(0.138)$ & $(0.050)$ \\
\hline \multirow[t]{2}{*}{ Deposits/Assets } & -0.013 & -0.018 & 0.007 \\
\hline & $(0.049)$ & $(0.052)$ & $(0.013)$ \\
\hline \multirow[t]{2}{*}{ Size } & 0.007 & -0.004 & $0.011^{* *}$ \\
\hline & $(0.017)$ & $(0.015)$ & $(0.006)$ \\
\hline \multirow[t]{2}{*}{ Branches } & $-0.020^{* *}$ & $-0.017^{*}$ & -0.002 \\
\hline & $(0.010)$ & $(0.009)$ & $(0.002)$ \\
\hline \multirow[t]{2}{*}{ Equity/Assets } & 0.067 & 0.008 & $0.073^{* *}$ \\
\hline & $(0.064)$ & $(0.076)$ & $(0.036)$ \\
\hline Bank fixed-effects & Yes & Yes & Yes \\
\hline Time fixed-effects & Yes & Yes & Yes \\
\hline Observations & 918 & 906 & 917 \\
\hline
\end{tabular}

Notes: This table presents the estimated results for model (1). Columns (1)-(3) show the results for the regressions with NPL (total), NPL (firms), and NPL (individuals) as the dependent variables, respectively. In all regressions, a constant term, bank and time fixed effects are included but not reported. Robust standard errors are presented in parentheses. NPL (firms), NPL (individuals), and NPL (total) are the ratios of non-performing loans issued to firms, to individuals and total non-performing loans divided by total loans, respectively. Wholesale funding is the ratio of deposits from non-bank financial institutions to total funding from customers. Size is the natural logarithm of total assets. Equity is the ratio of total equity to total assets. Deposits/Assets is the ratio of total deposits to total assets. Provisions is the ratio of loan loss provisions to total assets. Branches is the natural logarithm of total bank branches. ${ }^{*},{ }^{* *}$, and ${ }^{* * *}$ denote $10 \%, 5 \%$, and $1 \%$ significance levels, respectively. 
Table 4. Effects of the conflict and distance from the head office to the conflict on loan growth

\begin{tabular}{|c|c|c|c|}
\hline & $\begin{array}{l}\text { Loan } \\
\text { growth } \\
\text { (total) }\end{array}$ & $\begin{array}{l}\text { Loan } \\
\text { growth } \\
\text { (firms) }\end{array}$ & $\begin{array}{l}\text { Loan } \\
\text { growth } \\
\text { (individuals) }\end{array}$ \\
\hline & (1) & $(2)$ & (3) \\
\hline Share of total loans in Donetsk and Luhansk & $-7.191^{*}$ & $-9.845^{* *}$ & $-19.750^{* * *}$ \\
\hline \multicolumn{4}{|l|}{${ }^{*}$ Conflict } \\
\hline & (3.785) & (3.833) & (7.068) \\
\hline Share of total loans in Donetsk and Luhansk & $1.119^{*}$ & $1.588^{* *}$ & $3.127^{* *}$ \\
\hline \multicolumn{4}{|l|}{${ }^{*}$ Distance from Headquarters to conflict ${ }^{\star}$ Conflict } \\
\hline & $(0.642)$ & $(0.653)$ & $(1.207)$ \\
\hline \multirow[t]{2}{*}{ Wholesale funding } & 0.024 & 0.168 & $0.641^{* *}$ \\
\hline & $(0.141)$ & $(0.249)$ & $(0.306)$ \\
\hline \multirow[t]{2}{*}{ Provisions } & -0.382 & 0.884 & $1.486^{*}$ \\
\hline & $(0.345)$ & $(1.070)$ & $(0.807)$ \\
\hline \multirow[t]{2}{*}{ Deposits/Assets } & 0.040 & -0.093 & $-0.899 * *$ \\
\hline & $(0.302)$ & $(0.584)$ & $(0.392)$ \\
\hline \multirow[t]{2}{*}{ Size } & $-0.251^{* * *}$ & -0.162 & -0.186 \\
\hline & $(0.056)$ & $(0.135)$ & $(0.113)$ \\
\hline \multirow[t]{2}{*}{ Branches } & $0.052^{*}$ & $0.095^{* *}$ & -0.145 \\
\hline & $(0.027)$ & $(0.047)$ & $(0.099)$ \\
\hline \multirow[t]{2}{*}{ Equity/Assets } & -0.349 & -0.448 & $-1.686^{\star *}$ \\
\hline & $(0.391)$ & $(0.839)$ & $(0.655)$ \\
\hline Bank fixed-effects & Yes & Yes & Yes \\
\hline Time fixed-effects & Yes & Yes & Yes \\
\hline Observations & 869 & 869 & 868 \\
\hline
\end{tabular}

Notes: This table presents the estimated results for model (1). Columns (1)-(3) show the results for the regressions with NPL (total), NPL (firms), and NPL (individuals) as the dependent variables, respectively. In all regressions, a constant term, bank and time fixed effects are included but not reported. Robust standard errors are presented in parentheses. NPL (firms), NPL (individuals), and NPL (total) are the ratios of non-performing loans issued to firms, to individuals and total non-performing loans divided by total loans, respectively. Wholesale funding is the ratio of deposits from non-bank financial institutions to total funding from customers. Size is the natural logarithm of total assets. Equity is the ratio of total equity to total assets. Deposits/Assets is the ratio of total deposits to total assets. Provisions is the ratio of loan loss provisions to total assets. Branches is the natural logarithm of total bank branches. ${ }^{*},{ }^{* *}$, and ${ }^{* * *}$ denote $10 \%, 5 \%$, and $1 \%$ significance levels, respectively. 
Table 5. Shock transmission to other market zones

\begin{tabular}{|c|c|c|c|}
\hline & Zone 1 & Zone 2 & Zone 3 \\
\hline & (1) & $(2)$ & (3) \\
\hline & \multicolumn{3}{|c|}{ Panel A. NPL (total) } \\
\hline \multirow[t]{3}{*}{ Share of total loans in Donetsk and Luhansk ${ }^{*}$ Conflict } & 0.002 & -0.005 & 0.018 \\
\hline & $(0.003)$ & $(0.005)$ & $(0.026)$ \\
\hline & \multicolumn{3}{|c|}{ Panel B. NPL (firms) } \\
\hline \multirow[t]{3}{*}{ Share of loans to firms in Donetsk and Luhansk ${ }^{*}$ Conflict } & 0.003 & -0.004 & 0.018 \\
\hline & $(0.003)$ & $(0.006)$ & $(0.029)$ \\
\hline & \multicolumn{3}{|c|}{ Panel B. NPL (firms) } \\
\hline \multirow[t]{2}{*}{ Share of loans to individuals in Donetsk and Luhansk ${ }^{*}$ Conflict } & $0.021^{* * *}$ & $0.011^{* *}$ & 0.046 \\
\hline & $(0.006)$ & $(0.005)$ & $(0.031)$ \\
\hline Bank fixed-effects & Yes & Yes & Yes \\
\hline Time fixed-effects & Yes & Yes & Yes \\
\hline Observations & 918 & 918 & 918 \\
\hline
\end{tabular}

Notes: This table presents the estimated results for model (1) across different market zones. Columns (1)-(3) show the results for the regressions with NPL ratios in Zone 1, Zone 2, and Zone 3, respectively. Panels A-C show the results for NPL (total), NPL (firms), and NPL (individuals) as the dependent variables, respectively. In all regressions, the constant term, control variables, as well as bank and time fixed effects are included but not reported. Robust standard errors are presented in parentheses. NPL (firms), NPL (individuals), and NPL (total) are the ratios of non-performing loans issued to firms, to individuals, and total non-performing loans over total loans, respectively. ${ }^{*},{ }^{* *}$, and ${ }^{* * *}$ denote $10 \%, 5 \%$, and $1 \%$ significance levels, respectively. 
Table 6. Shock contagion

\begin{tabular}{|c|c|c|c|}
\hline & $\begin{array}{l}\text { NPL } \\
\text { (total) }\end{array}$ & $\begin{array}{l}\text { NPL } \\
\text { (firms) }\end{array}$ & $\begin{array}{l}\text { NPL } \\
\text { (individuals) }\end{array}$ \\
\hline & (1) & $(2)$ & (3) \\
\hline \multirow[t]{2}{*}{ Share of total loans in Donetsk and Luhansk *Conflict } & $31.324^{*}$ & & \\
\hline & $(17.722)$ & & \\
\hline \multirow[t]{2}{*}{ Share of total loans in Donetsk and Luhansk *Distance to conflict ${ }^{*}$ Conflict } & $-5.346^{*}$ & & \\
\hline & $(2.969)$ & & \\
\hline \multirow[t]{2}{*}{ Share of loans to firms in Donetsk and Luhansk ${ }^{*}$ Conflict } & & 25.172 & \\
\hline & & $(19.058)$ & \\
\hline \multirow[t]{2}{*}{ Share of loans to firms in Donetsk and Luhansk ${ }^{*}$ Distance to conflict ${ }^{*}$ Conflict } & & -4.100 & \\
\hline & & $(3.115)$ & \\
\hline \multirow[t]{2}{*}{ Share of loans to individuals in Donetsk and Luhansk ${ }^{*}$ Conflict } & & & 15.314 \\
\hline & & & $(13.070)$ \\
\hline \multirow[t]{2}{*}{ Share of loans to individuals in Donetsk and Luhansk ${ }^{*}$ Distance to conflict ${ }^{*}$ Conflict } & & & -3.049 \\
\hline & & & $(2.256)$ \\
\hline Bank fixed-effects & Yes & Yes & Yes \\
\hline Market $\times$ Time fixed-effects & Yes & Yes & Yes \\
\hline Observations & 6,248 & 5,924 & 6,092 \\
\hline
\end{tabular}

Notes: This table presents the estimated results for model (5). Columns (1)-(3) show the results for the regressions with NPL (total), NPL (firms), and NPL (individuals) as the dependent variables, respectively. In all regressions, the constant term, control variables, as well as bank, region, and time fixed effects are included but not reported. Robust standard errors are presented in parentheses. NPL (firms), NPL (individuals), and NPL (total) are the ratios of non-performing loans issued to firms, to individuals, and total nonperforming loans over total loans, respectively. Distance to conflict is the natural logarithm of the geodesic distance from the market to the city of Donetsk. ${ }^{*},{ }^{* *}$, and ${ }^{* * *}$ denote $10 \%, 5 \%$, and $1 \%$ significance levels, respectively. 
Table 7. Post-conflict lending behavior

\begin{tabular}{|c|c|c|c|}
\hline & $\begin{array}{l}\text { Loan } \\
\text { growth } \\
\text { (total) }\end{array}$ & $\begin{array}{l}\text { Loan } \\
\text { growth } \\
\text { (firms) }\end{array}$ & $\begin{array}{l}\text { Loan } \\
\text { growth } \\
\text { (individuals) }\end{array}$ \\
\hline & (1) & $(2)$ & (3) \\
\hline \multirow[t]{2}{*}{ Share of total loans in Donetsk and Luhansk *Distance to headquarters ${ }^{*}$ Conflict } & $-0.300^{* *}$ & $-0.344^{*}$ & $-0.311^{* *}$ \\
\hline & $(0.141)$ & $(0.184)$ & $(0.157)$ \\
\hline \multirow[t]{2}{*}{ Share of total loans in Donetsk and Luhansk *Conflict } & 0.213 & 0.944 & 0.031 \\
\hline & $(0.397)$ & $(0.728)$ & $(0.592)$ \\
\hline Bank fixed-effects & Yes & Yes & Yes \\
\hline Market $\times$ Time fixed-effects & Yes & Yes & Yes \\
\hline Observations & 6,623 & 6,577 & 6,618 \\
\hline
\end{tabular}

Notes: This table presents the estimated results for model (7). Columns (1)-(3) show the results for the regressions with Loan growth (total), Loan growth (firms), and Loan growth (individuals) as the dependent variables, respectively. In all regressions, the constant term, control variables, as well as bank, region, and time fixed effects are included but not reported. Robust standard errors are presented in parentheses. Loan growth (total), Loan growth (firms), and Loan growth (individuals) are the difference in the natural logarithm of the total loan amount granted, the loan amount granted to firms, and the loan amount granted to individuals, respectively. Distance to headquarters is the natural logarithm of the geodesic distance from the market to Headquarters. ${ }^{* * *}$, and ${ }^{* * *}$ denote $10 \%$, $5 \%$, and $1 \%$ significance levels, respectively. 
Table 8. Robustness check

\begin{tabular}{|c|c|c|c|c|}
\hline & Q2 2014 & Q3 2014 & Q4 2014 & Q1 2015 \\
\hline & (1) & $(2)$ & (3) & $(4)$ \\
\hline & \multicolumn{4}{|c|}{ Panel A. NPL ratio } \\
\hline \multirow[t]{2}{*}{ Share of total loans in Donetsk and Luhansk } & 31.944 & $46.929^{* *}$ & $79.473^{* *}$ & 8.054 \\
\hline & $(36.068)$ & $(18.897)$ & $(33.145)$ & $(18.861)$ \\
\hline \multirow[t]{2}{*}{ Share of total loans in Donetsk and Luhansk ${ }^{*}$ Distance to conflict } & -4.532 & $-5.545^{\star *}$ & $-8.742^{*}$ & -0.916 \\
\hline & $(5.760)$ & $(2.697)$ & $(4.853)$ & $(2.789)$ \\
\hline \multirow{2}{*}{ Observations } & 788 & 755 & 717 & 689 \\
\hline & \multicolumn{4}{|c|}{ Panel B. Loan growth } \\
\hline \multirow[t]{2}{*}{ Share of total loans in Donetsk and Luhansk } & $-1.547^{*}$ & -1.448 & $-5.258^{* * *}$ & -1.478 \\
\hline & $(0.827)$ & $(1.100)$ & $(1.269)$ & $(1.110)$ \\
\hline \multirow[t]{2}{*}{ Share of total loans in Donetsk and Luhansk ${ }^{*}$ Distance to headquarters } & -0.170 & -0.750 & $-0.577^{*}$ & -0.195 \\
\hline & $(0.114)$ & $(0.553)$ & $(0.320)$ & $(0.140)$ \\
\hline Observations & 827 & 812 & 770 & 737 \\
\hline
\end{tabular}

Notes: This table presents the results of repeated regressions for models (9) and (10). Columns (1)-(4) show the results for individual quarters from Q2 2014 to Q1 2015. Panels A and B show the results for the estimations with NPL ratio and Loan growth as the dependent variables, respectively. In all regressions, the constant term, control variables, as well as bank, region, and time fixed effects are included but not reported. Robust standard errors are presented in parentheses. Distance to conflict is the natural logarithm of the geodesic distance from a market to the city of Donetsk. Distance to headquarters is the natural logarithm of the geodesic distance from the market to Headquarters. ${ }^{*},{ }^{* *}$, and ${ }^{* * *}$ denote $10 \%, 5 \%$, and $1 \%$ significance levels, respectively. 


\section{Figures}

Figure 1. Number of banks and average total assets (2009-2016)

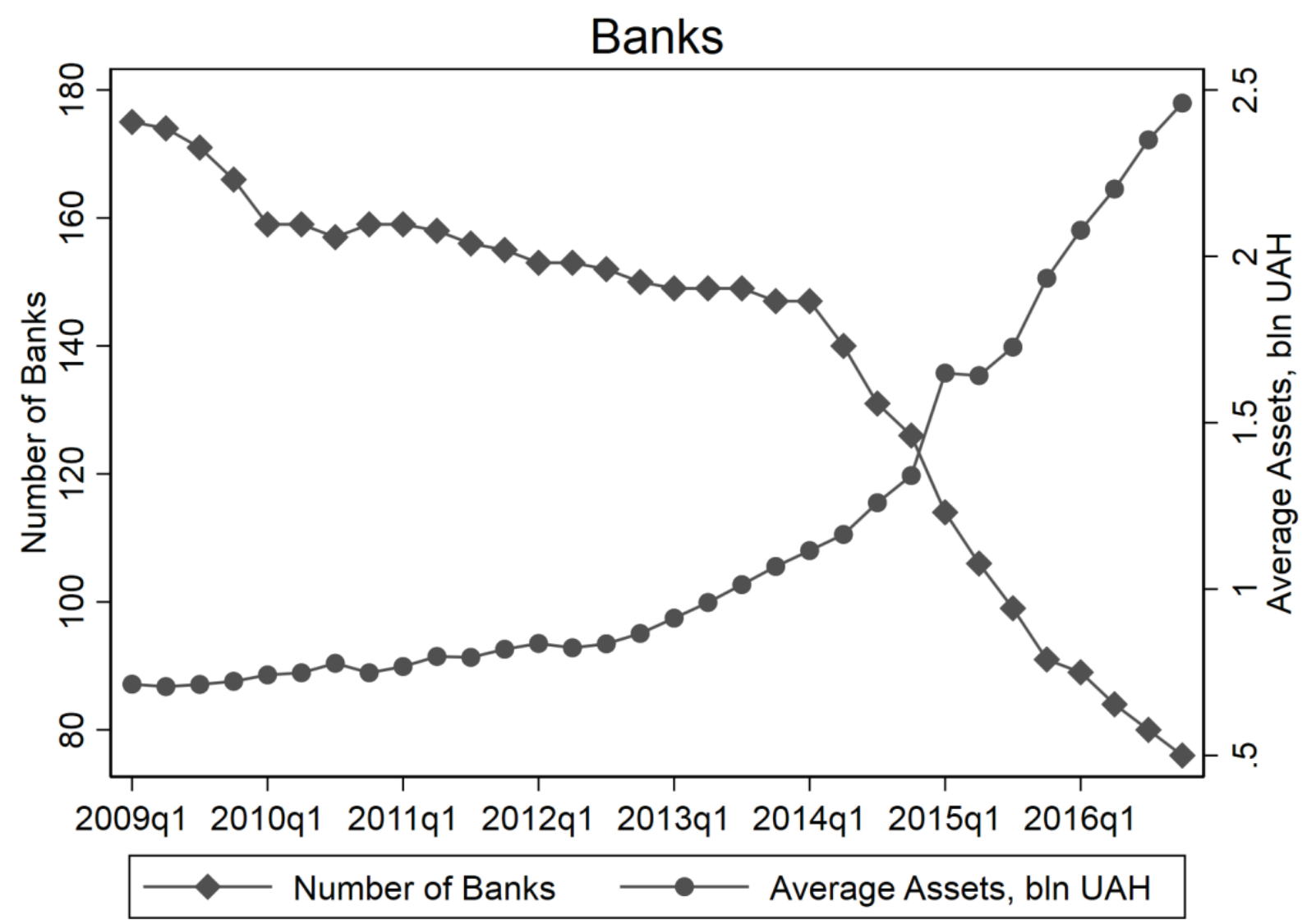


Figure 2. Map of Ukraine

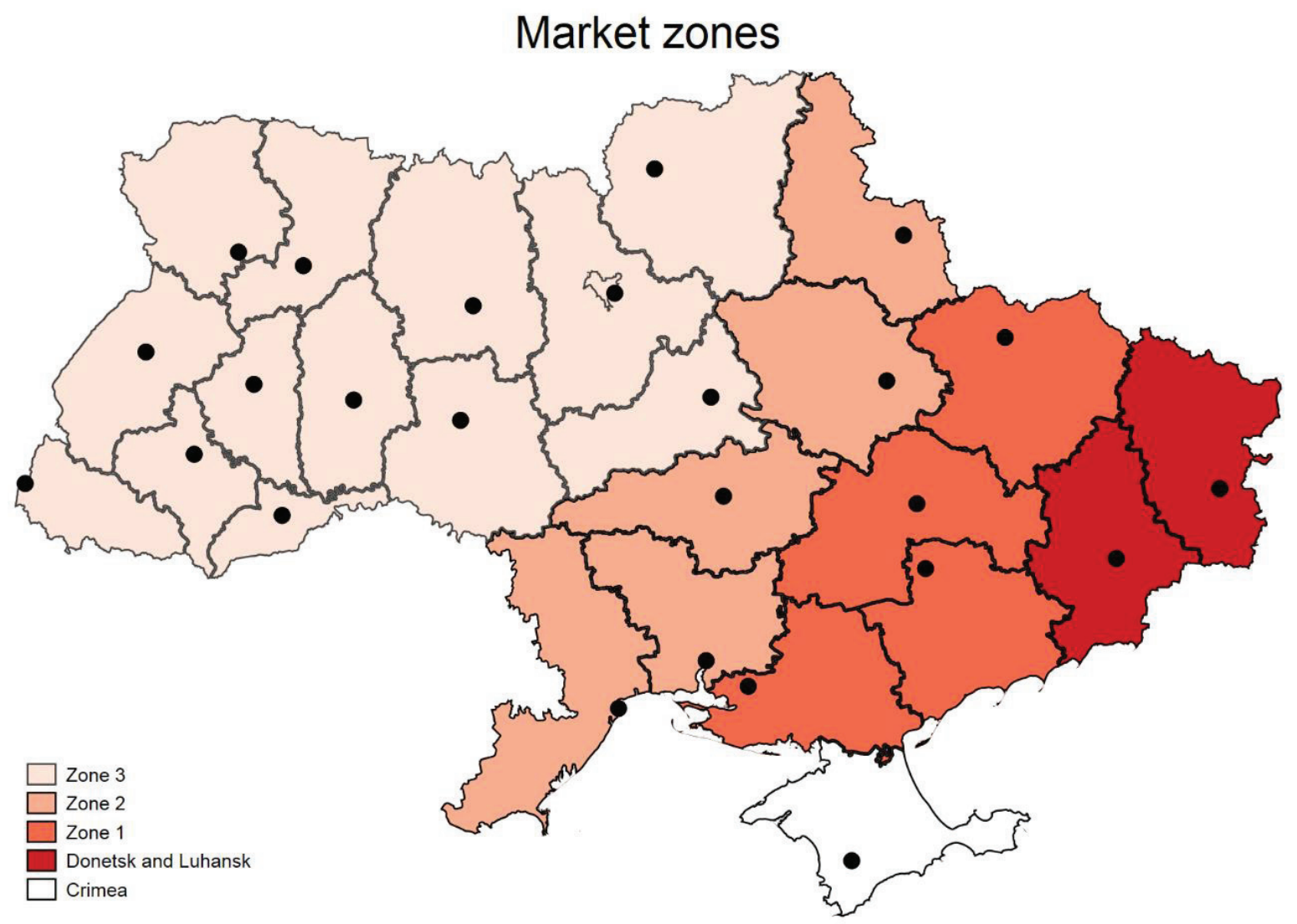

Notes: This figure shows the map of Ukraine with Ukrainian regions are grouped into different market groups in relation with the conflict zones. 
Figure 3. Loan growth and NPL ratio by share of loans in Luhansk and Donetsk as of Q1 2014

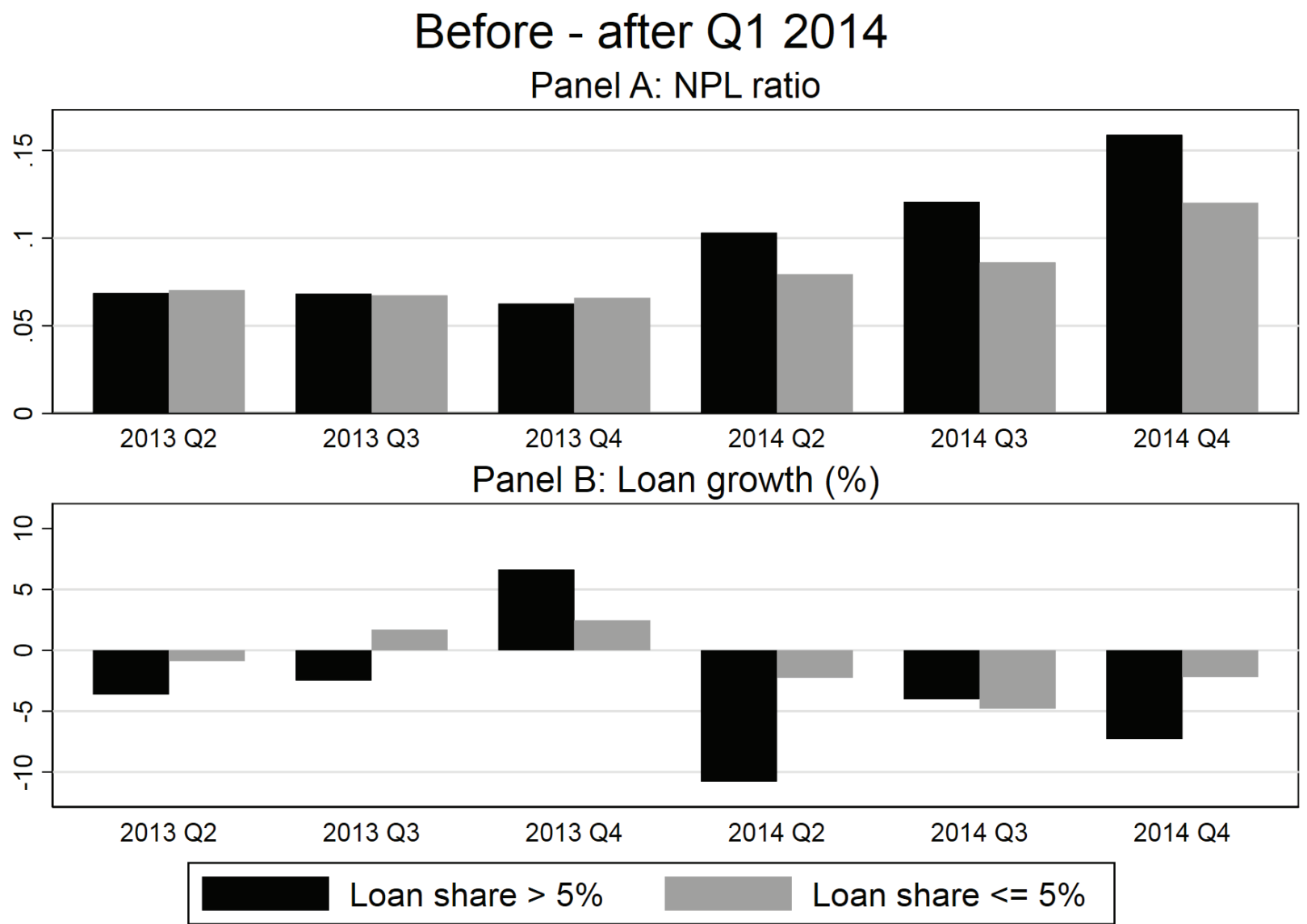

Notes: This figure shows the evolution of loan growth and NPL ratio of two groups of banks: one group consists of banks having $5 \%$ or less share of loans outstanding in Luhansk and Donetsk as of Q1 2014 and another group consists of banks having more than 5\% share of loans outstanding in Luhansk and Donetsk as of Q1 2014. 
Figure 4. Impact of Loan share in Donetsk and Luhansk on the NPL ratio over time

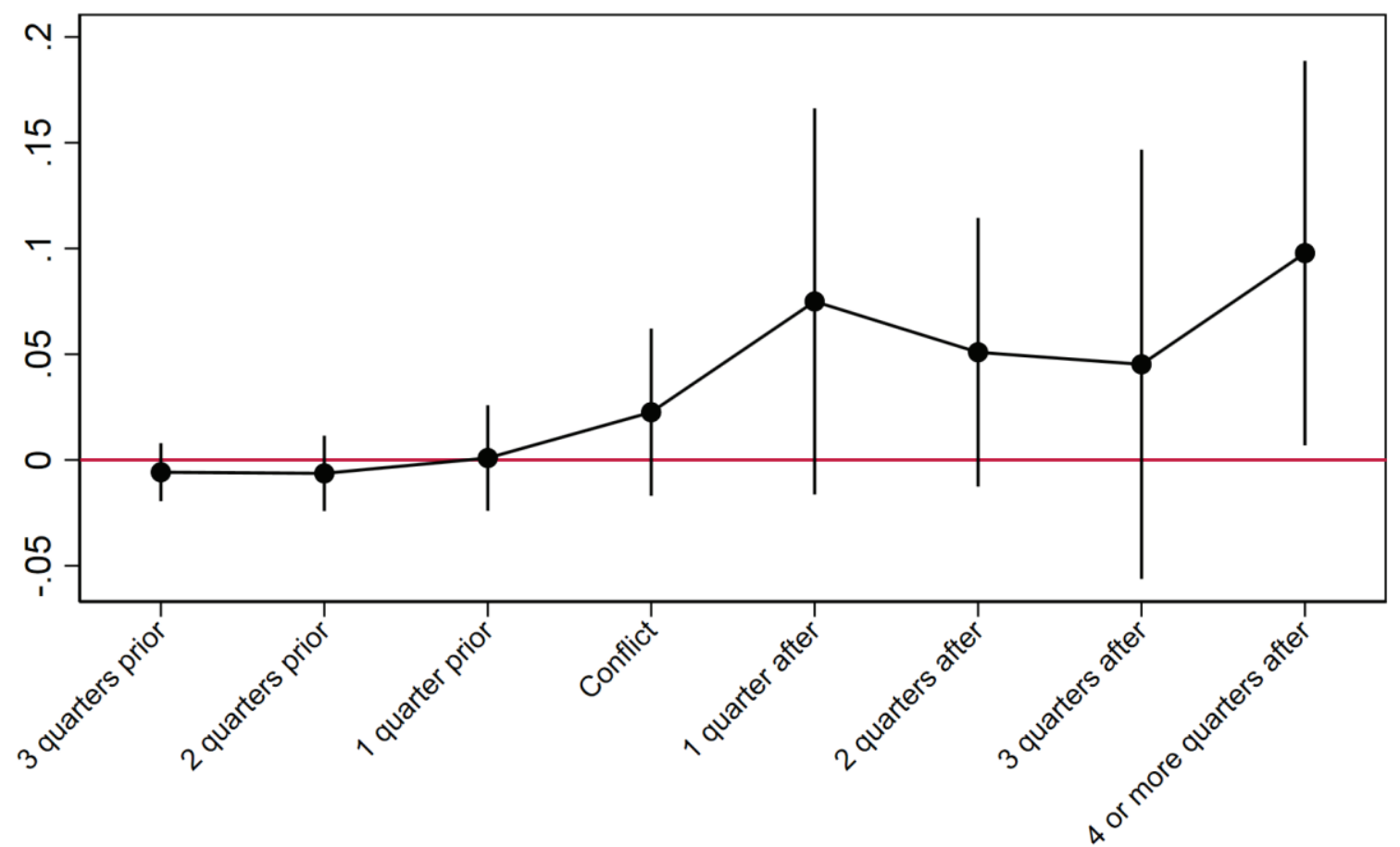

Notes: The quarterly figures represent the lead and lag effects of the share of loans in Donetsk and Luhansk on the non-performing loan ratio. 
Figure 5. Impact of Loan share in Donetsk and Luhansk on loan growth over time

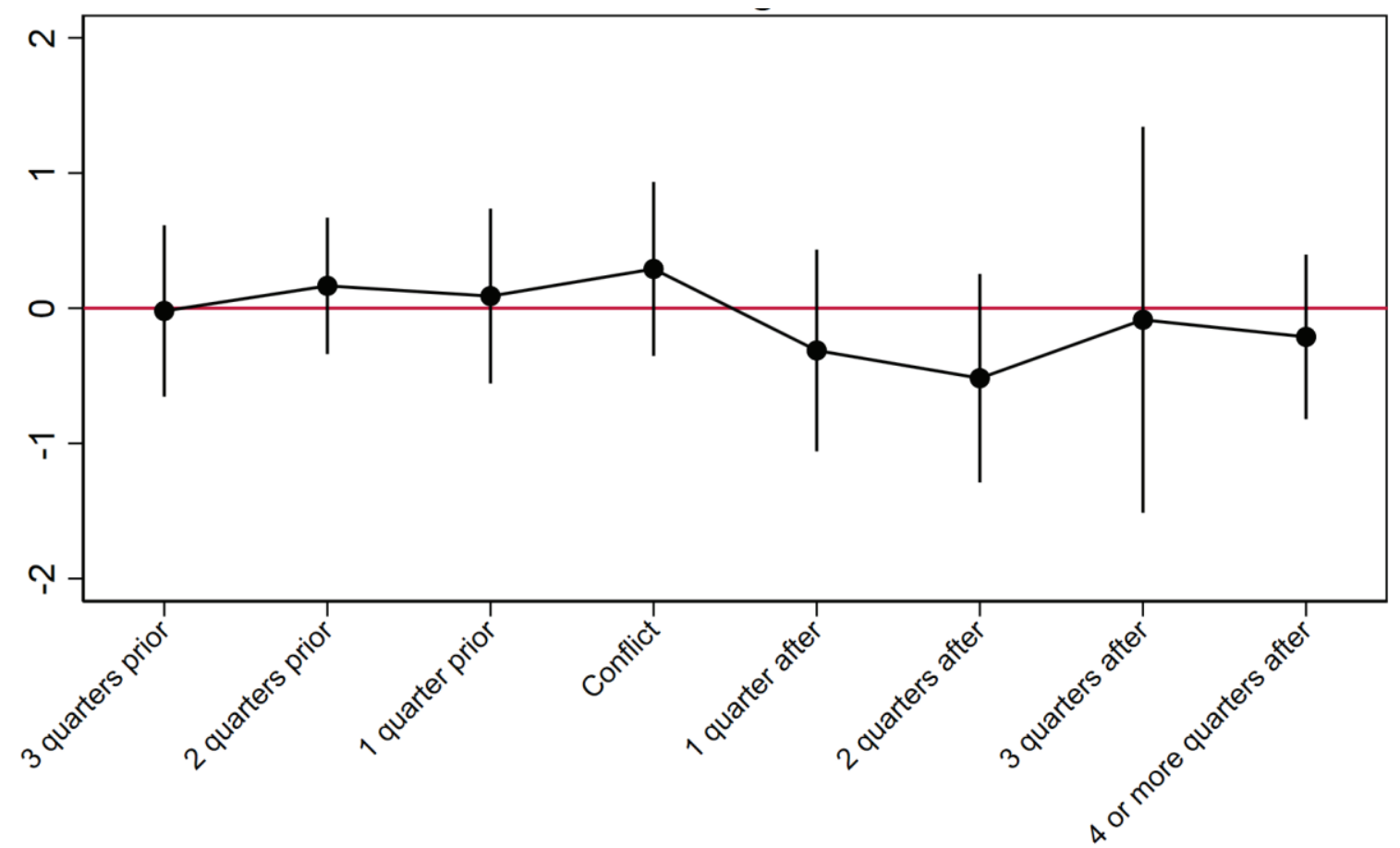

Notes: The quarterly figures represent the lead and lag effects of the share of loans in Donetsk and Luhansk on loan growth. 
Figure 6. Impact of the interaction between Loan share in Donetsk and Luhansk and Distance to conflict on the NPL ratio over time

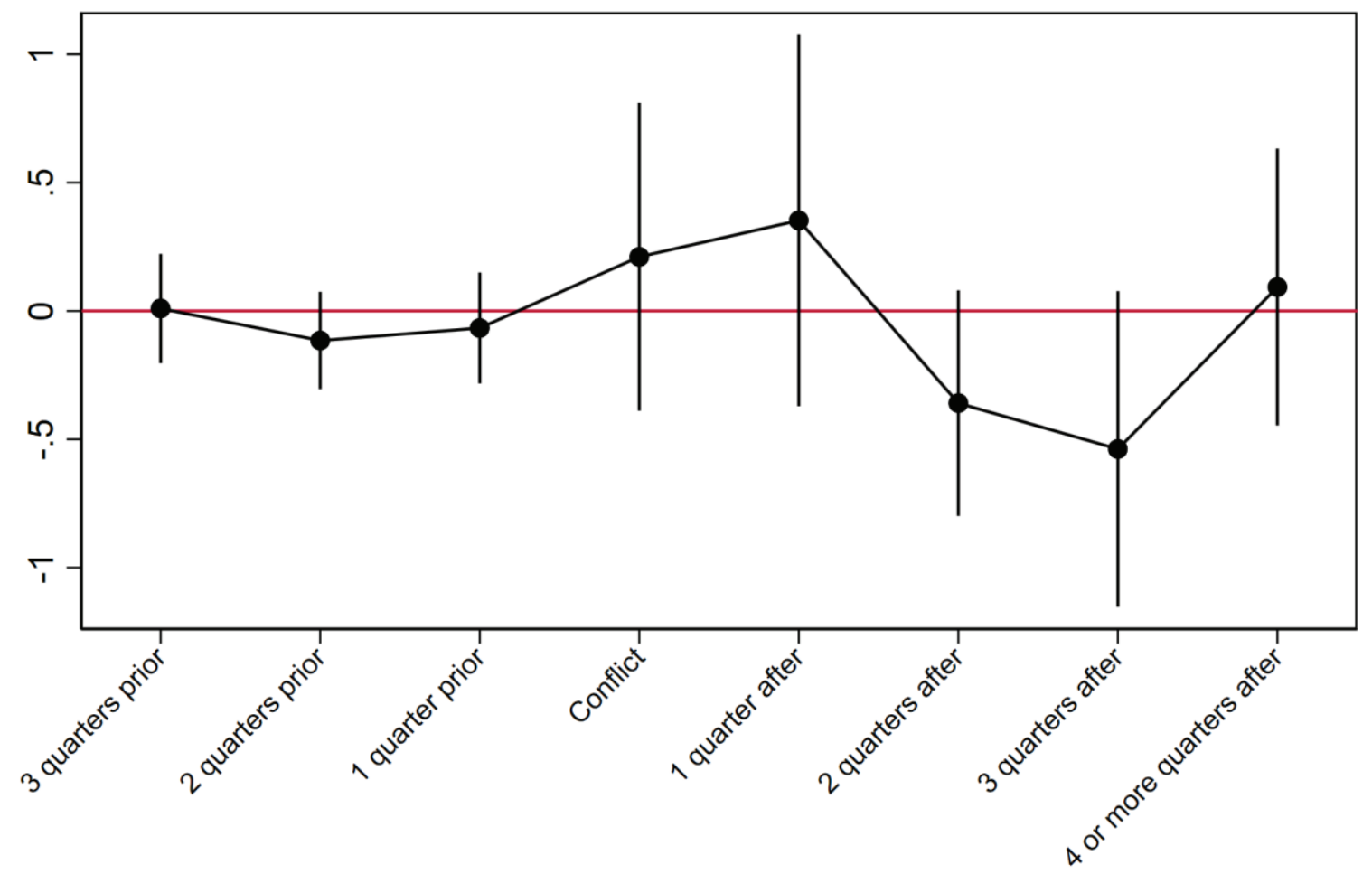

Notes: The quarterly figures represent the lead and lag effects of the interaction between share of loans in Donetsk and Luhansk and Distance to conflict on the non-performing loan ratio. 
Figure 7. Marginal effects of the triple interaction on the NPL ratio

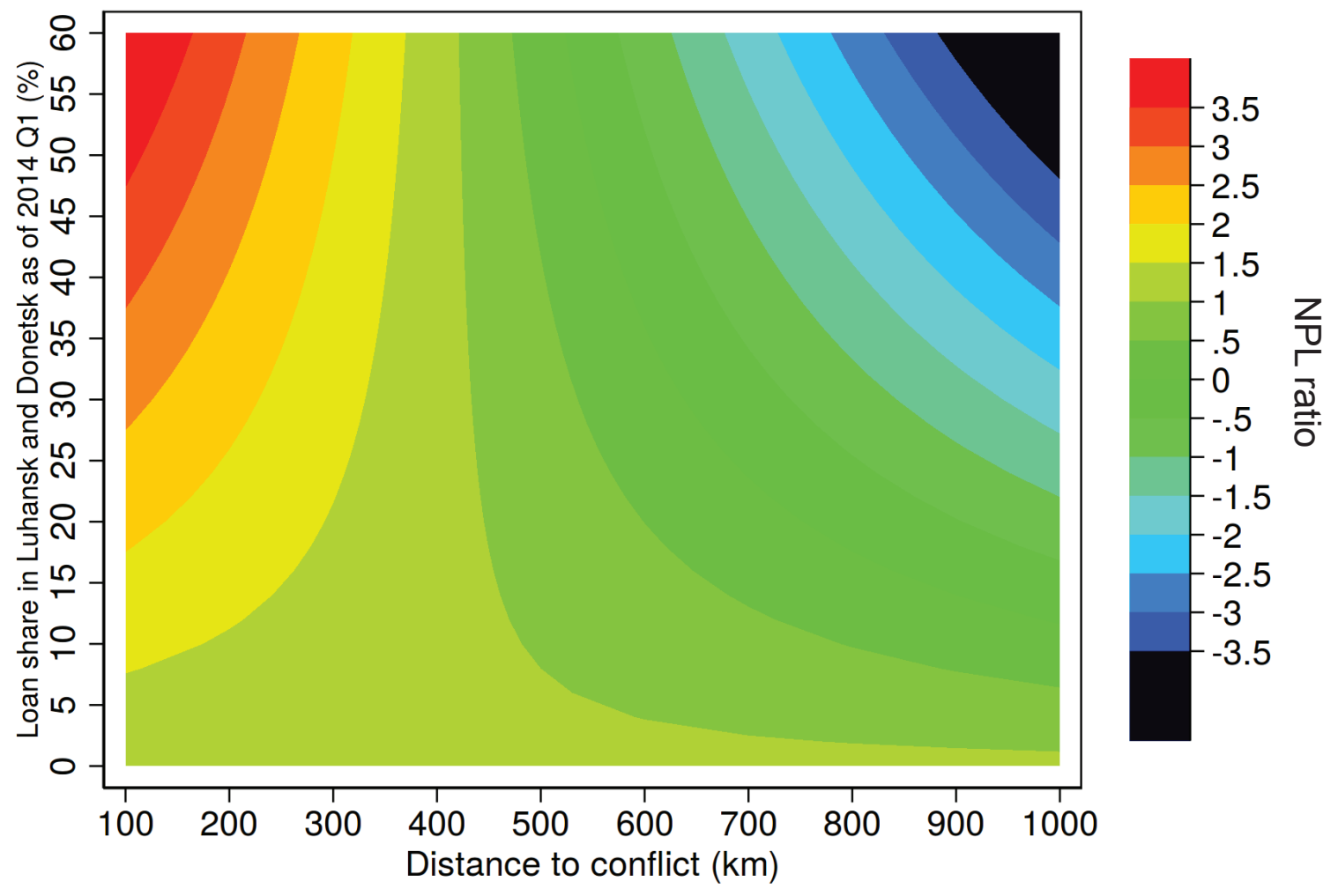

Notes: This figure shows the marginal effects of Loan share in Luhansk and Donetsk as of Q1 2014 and Distance to conflict on the NPL ratio, holding other variables at their means. 
Figure 8. Marginal effects of Loan share in Donetsk and Luhansk on the NPL ratio with distance to conflict

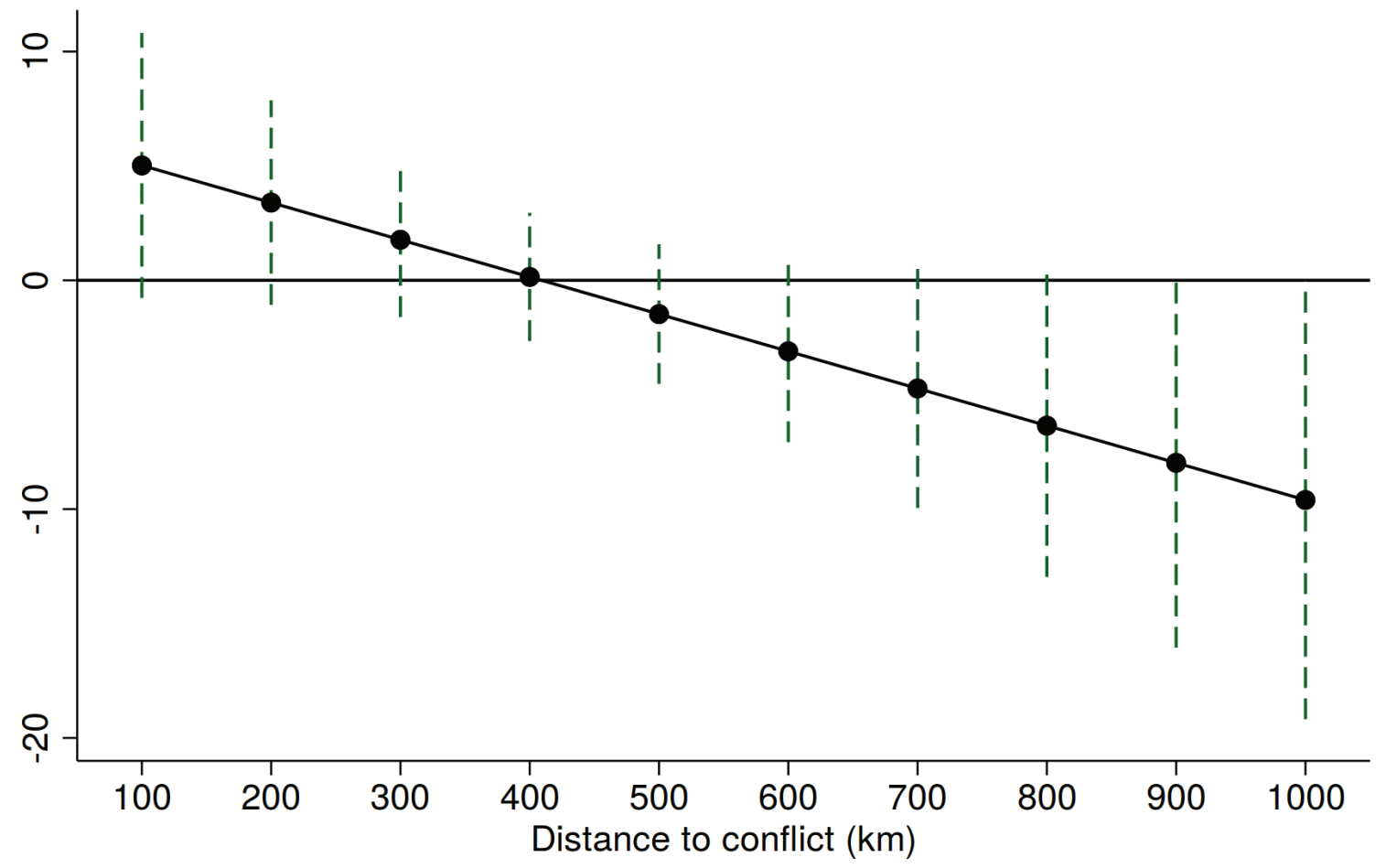

Notes: This figure shows the sensitivity of the effect of Loan share in Luhansk and Donetsk as of Q1 2014 on the NPL ratio with changes in Distance to conflict, holding other variables at their means. 
Figure 9. Impact of the interaction between Loan share in Donetsk and Luhansk and Distance to Headquarter on loan growth over time

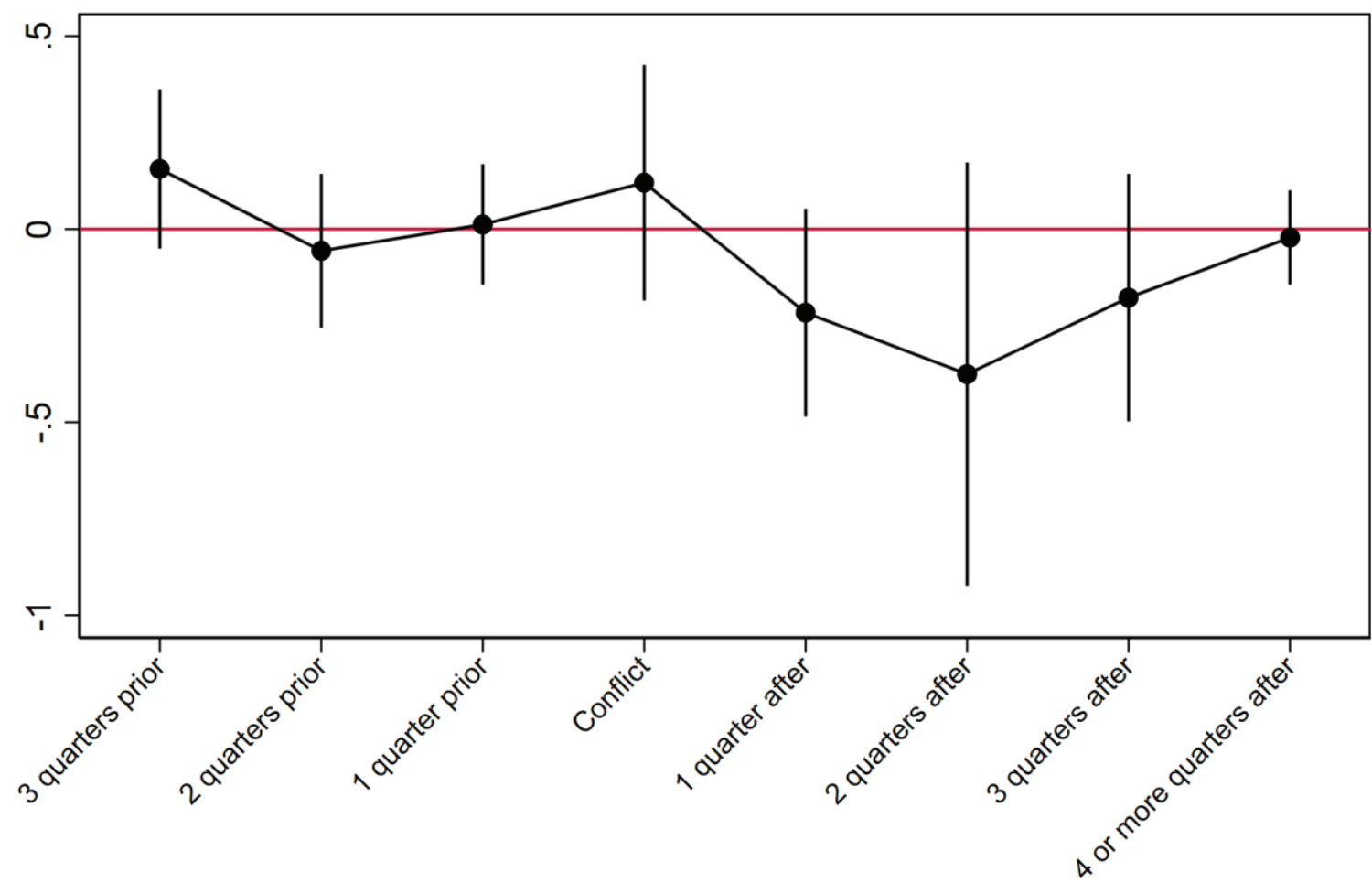

Notes: The quarterly figures represent the lead and lag effects of the interaction between share of loans in Donetsk and Luhansk and Distance to headquarters on loan growth. 
Figure 10. Marginal effects of the triple interaction on loan growth

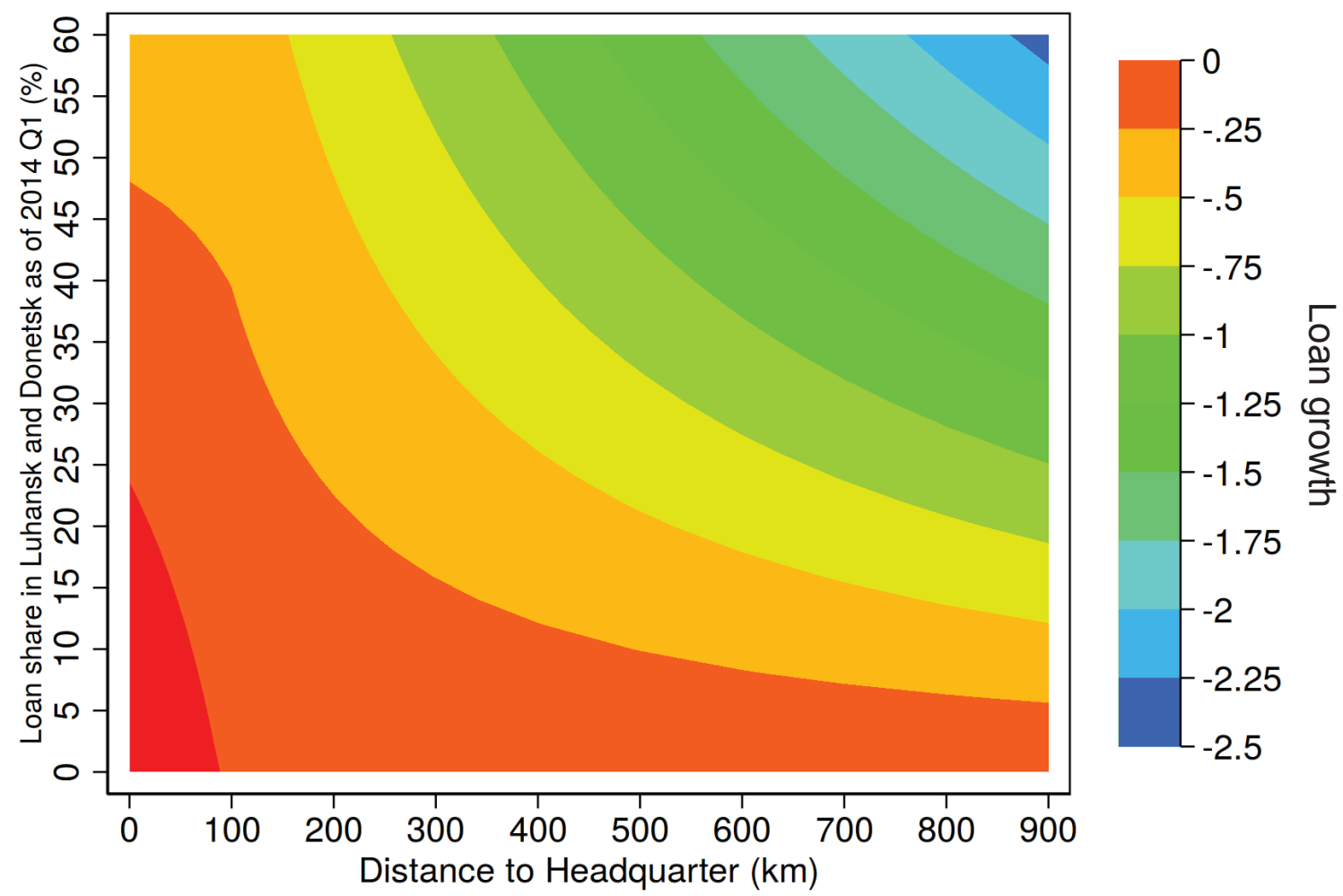

Notes: This figure shows the marginal effects of Loan share in Luhansk and Donetsk as of Q1 2014 and Distance to headquarters on loan growth, holding other variables at their means. 
Figure 11. Marginal effects of loan share in Donetsk and Luhansk on loan growth with distance to headquarter

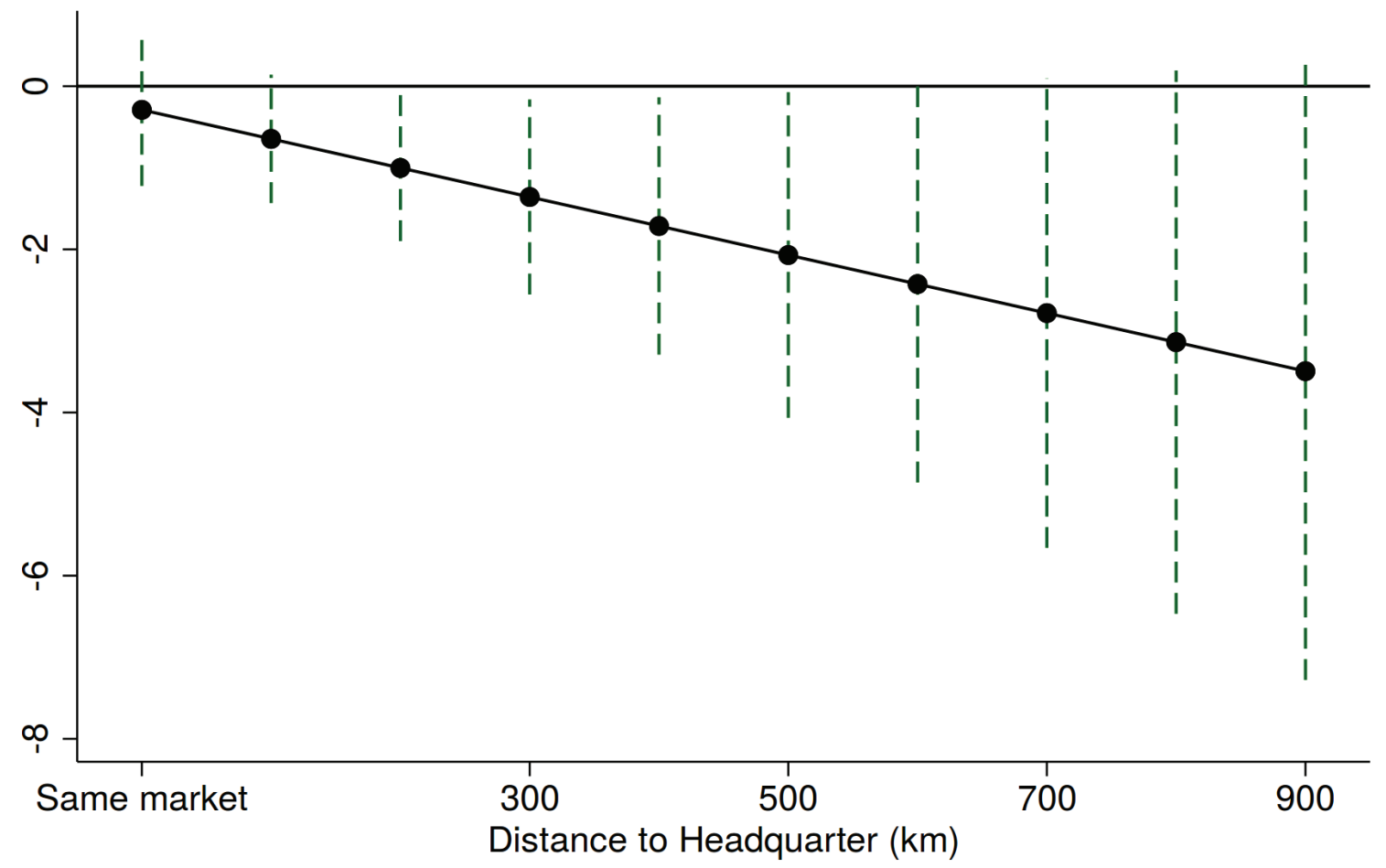

Notes: This figure shows the sensitivity of the effect of Loan share in Luhansk and Donetsk as of Q1 2014 on loan growth with changes in Distance to headquarters, holding other variables at their means. 


\section{APPENDIX A}

Appendix A 1. Table of results for shock contagion reporting all variables

\begin{tabular}{|c|c|c|c|}
\hline & $\begin{array}{l}\text { NPL } \\
\text { (total) }\end{array}$ & $\begin{array}{l}\text { NPL } \\
\text { (firms) }\end{array}$ & $\begin{array}{l}\text { NPL } \\
\text { (individuals) }\end{array}$ \\
\hline & (1) & (2) & (3) \\
\hline & \multicolumn{3}{|c|}{ Panel A. Zone 1} \\
\hline \multirow[t]{2}{*}{ Share of total loans in Donetsk and Luhansk *Conflict } & 0.002 & & \\
\hline & $(0.003)$ & & \\
\hline \multirow[t]{2}{*}{ Share of loans to firms in Donetsk and Luhansk *Conflict } & & 0.003 & \\
\hline & & $(0.003)$ & \\
\hline \multirow[t]{2}{*}{ Share of loans to individuals in Donetsk and Luhansk *Conflict } & & & $0.021^{* * *}$ \\
\hline & & & $(0.006)$ \\
\hline \multirow[t]{2}{*}{ Wholesale funding } & -0.013 & -0.009 & -0.005 \\
\hline & $(0.013)$ & $(0.012)$ & $(0.004)$ \\
\hline \multirow[t]{2}{*}{ Provisions } & 0.029 & 0.026 & 0.002 \\
\hline & $(0.018)$ & $(0.016)$ & $(0.003)$ \\
\hline \multirow[t]{2}{*}{ Deposits/Assets } & -0.012 & -0.013 & 0.001 \\
\hline & $(0.011)$ & $(0.010)$ & $(0.002)$ \\
\hline \multirow[t]{2}{*}{ Size } & 0.003 & 0.002 & -0.001 \\
\hline & $(0.004)$ & $(0.004)$ & $(0.001)$ \\
\hline \multirow[t]{2}{*}{ Branches } & 0.002 & 0.002 & -0.000 \\
\hline & $(0.002)$ & $(0.002)$ & $(0.000)$ \\
\hline \multirow[t]{2}{*}{ Equity/Assets } & 0.001 & 0.000 & -0.000 \\
\hline & $(0.009)$ & $(0.008)$ & $(0.002)$ \\
\hline \multirow[t]{2}{*}{ Observations } & 918 & 918 & 918 \\
\hline & Panel B. & & \\
\hline \multirow[t]{2}{*}{ Share of total loans in Donetsk and Luhansk *Conflict } & -0.005 & & \\
\hline & $(0.005)$ & & \\
\hline \multirow[t]{2}{*}{ Share of loans to firms in Donetsk and Luhansk *Conflict } & & -0.004 & \\
\hline & & $(0.006)$ & \\
\hline \multirow[t]{2}{*}{ Share of loans to individuals in Donetsk and Luhansk *Conflict } & & & $0.011^{* *}$ \\
\hline & & & $(0.005)$ \\
\hline \multirow[t]{2}{*}{ Wholesale funding } & $-0.046^{*}$ & $-0.044^{*}$ & $-0.002^{* *}$ \\
\hline & $(0.024)$ & $(0.024)$ & $(0.001)$ \\
\hline \multirow[t]{2}{*}{ Provisions } & 0.019 & 0.024 & 0.003 \\
\hline & $(0.045)$ & $(0.048)$ & $(0.004)$ \\
\hline \multirow[t]{2}{*}{ Deposits/Assets } & 0.013 & 0.014 & -0.000 \\
\hline & $(0.010)$ & $(0.011)$ & $(0.001)$ \\
\hline \multirow[t]{2}{*}{ Size } & 0.004 & 0.003 & 0.001 \\
\hline & $(0.003)$ & $(0.003)$ & $(0.001)$ \\
\hline \multirow[t]{2}{*}{ Branches } & -0.002 & -0.002 & 0.000 \\
\hline & $(0.001)$ & $(0.001)$ & $(0.000)$ \\
\hline \multirow[t]{2}{*}{ Equity/Assets } & -0.002 & -0.003 & 0.001 \\
\hline & $(0.006)$ & $(0.006)$ & $(0.001)$ \\
\hline Observations & 918 & 918 & 918 \\
\hline
\end{tabular}




\begin{tabular}{ll}
\hline & Panel C. Zone 3 \\
\hline Share of total loans in Donetsk and Luhansk ${ }^{*}$ Conflict & 0.018 \\
Share of loans to firms in Donetsk and Luhansk ${ }^{*}$ Conflict & $(0.026)$
\end{tabular}

Share of loans to firms in Donetsk and Luhansk *Conflict

Wholesale funding

$\begin{array}{lll}-0.003 & -0.015 & 0.010\end{array}$

Provisions

$0.217^{\text {** }}$

Deposits/Assets

Size

Branches

Equity/Assets

Notes: This table presents the estimated results for model (1) across different market zones. Columns (1)-(3) show the results for the regressions with NPL ratios in Zone 1, Zone 2, and Zone 3, respectively. Panels A-C show the results for NPL (total), NPL (firms) and NPL (individuals) as the dependent variables, respectively. In all regressions, the constant term, as well as bank and time fixed effects are included but not reported. Robust standard errors are presented in parentheses. NPL (firms), NPL (individuals), and NPL (total) are the ratios of non-performing loans issued to firms, to individuals, and total non-performing loans over total loans, respectively. Wholesale funding is the ratio of deposits from non-bank financial institutions to total funding from customers. Size is the natural logarithm of total assets. Equity is the ratio of total equity to total assets. Deposits/Assets is the ratio of total deposits to total assets. Provisions is the ratio of loan loss provisions to total assets. Branches is the natural logarithm of total bank branches. ${ }^{*},{ }^{* *}$, and ${ }^{* * *}$ denote $10 \%, 5 \%$, and $1 \%$ significance levels, respectively. 


\section{Appendix A 2. Table of results for model (5) reporting all variables}

\begin{tabular}{|c|c|c|c|}
\hline & $\begin{array}{l}\text { NPL } \\
\text { (total) }\end{array}$ & $\begin{array}{l}\text { NPL } \\
\text { (firms) }\end{array}$ & $\begin{array}{l}\text { NPL } \\
\text { (individuals) }\end{array}$ \\
\hline & $(1)$ & $(2)$ & (3) \\
\hline \multirow[t]{2}{*}{ Share of total loans in Donetsk and Luhansk ${ }^{*}$ Conflict } & $31.324^{*}$ & & \\
\hline & $(17.722)$ & & \\
\hline \multirow[t]{2}{*}{ Share of total loans in Donetsk and Luhansk *Distance to conflict ${ }^{*}$ Conflict } & $-5.346^{*}$ & & \\
\hline & $(2.969)$ & & \\
\hline \multirow[t]{2}{*}{ Share of loans to firms in Donetsk and Luhansk ${ }^{*}$ Conflict } & & 25.17 & \\
\hline & & $(19.058)$ & \\
\hline \multirow[t]{2}{*}{ Share of loans to firms in Donetsk and Luhansk ${ }^{*}$ Distance to conflict ${ }^{*}$ Conflict } & & -4.100 & \\
\hline & & $(3.115)$ & \\
\hline \multirow[t]{2}{*}{ Share of loans to individuals in Donetsk and Luhansk ${ }^{*}$ Conflict } & & & 15.314 \\
\hline & & & $(13.070)$ \\
\hline \multirow[t]{2}{*}{ Share of loans to individuals in Donetsk and Luhansk* Distance to conflict ${ }^{*}$ Conflict } & & & -3.049 \\
\hline & & & $(2.256)$ \\
\hline \multirow[t]{2}{*}{ Share of loans to firms } & -0.323 & -0.234 & -0.043 \\
\hline & $(0.232)$ & $(0.173)$ & $(0.044)$ \\
\hline \multirow[t]{2}{*}{ Share of loans to individuals } & 2.822 & 1.915 & 0.635 \\
\hline & $(2.229)$ & $(1.477)$ & $(0.611)$ \\
\hline \multirow[t]{2}{*}{ Number of other bank branches } & -101.300 & -105.002 & -15.509 \\
\hline & $(156.612)$ & $(101.159)$ & $(42.397)$ \\
\hline \multirow[t]{2}{*}{ Share of branches in the market } & -227.060 & -183.449 & -52.337 \\
\hline & $(201.229)$ & $(136.326)$ & $(54.643)$ \\
\hline \multirow[t]{2}{*}{ Share of branches of the market } & $6.144^{* *}$ & $4.164^{* *}$ & $1.450^{* *}$ \\
\hline & $(2.718)$ & $(1.960)$ & $(0.702)$ \\
\hline Observations & 6,306 & 5,994 & 6,155 \\
\hline
\end{tabular}

Notes: This table presents the estimated results for model (5). Columns (1)-(3) show the results for the regressions with NPL (total), NPL (firms), and NPL (individuals) as the dependent variables, respectively. In all regressions, the constant term, as well as bank, region, and time fixed effects are included but not reported. Robust standard errors are presented in parentheses. NPL (firms), NPL (individuals), NPL (total) are the ratios of non-performing loans issued to firms, to individuals, and total non-performing loans over total loans, respectively. Share of loans to firms is the ratio of loans issued to firms by a bank in a market to that bank's total loans. Share of loans to individuals is the ratio of loans issued to individuals by a bank in a market to that bank's total loans. Share of branches in the market is the ratio of a bank's branches in a market to that bank's total branches. Number of other bank branches is the natural logarithm of the number of competitor bank branches in a market. Share of branches of the market is the ratio of bank branches in a market to the total number of bank branches. *, **, and ${ }^{* * *}$ denote $10 \%, 5 \%$, and $1 \%$ significance levels, respectively. 


\section{Appendix A 3. Table of results for model (7) reporting all variables}

\begin{tabular}{|c|c|c|c|}
\hline & $\begin{array}{l}\text { NPL } \\
\text { (total) }\end{array}$ & $\begin{array}{l}\text { NPL } \\
\text { (firms) }\end{array}$ & $\begin{array}{l}\text { NPL } \\
\text { (individuals) }\end{array}$ \\
\hline & (1) & $(2)$ & (3) \\
\hline \multirow[t]{2}{*}{ Share of total loans in Donetsk and Luhansk *Distance to Headquarters ${ }^{*}$ Conflict } & $-0.300^{* *}$ & $-0.344^{*}$ & $-0.311^{* *}$ \\
\hline & $(0.141)$ & $(0.184)$ & $(0.157)$ \\
\hline \multirow[t]{2}{*}{ Share of total loans in Donetsk and Luhansk *Conflict } & 0.213 & 0.944 & 0.031 \\
\hline & $(0.397)$ & $(0.728)$ & $(0.592)$ \\
\hline \multirow[t]{2}{*}{ Share of loans to firms } & -0.146 & -0.313 & $0.377^{*}$ \\
\hline & $(0.220)$ & $(0.224)$ & $(0.206)$ \\
\hline \multirow[t]{2}{*}{ Share of loans to individuals } & -0.651 & 1.065 & $-6.292^{* * *}$ \\
\hline & $(1.378)$ & $(1.275)$ & $(2.342)$ \\
\hline \multirow[t]{2}{*}{ Number of other bank branches } & 12.365 & -21.443 & -5.982 \\
\hline & $(41.422)$ & $(56.054)$ & $(35.455)$ \\
\hline \multirow[t]{2}{*}{ Number of branches } & 38.826 & 2.692 & 3.330 \\
\hline & $(54.132)$ & $(71.191)$ & $(47.340)$ \\
\hline \multirow[t]{2}{*}{ Share of branches in the market } & 0.224 & -0.685 & 0.748 \\
\hline & $(1.235)$ & $(1.031)$ & $(1.510)$ \\
\hline \multirow[t]{2}{*}{ Share of branches of the market } & 1.950 & 1.253 & $3.271^{* *}$ \\
\hline & $(1.591)$ & $(1.789)$ & $(1.485)$ \\
\hline Observations & 6,623 & 6,577 & 6,618 \\
\hline
\end{tabular}

Notes: This table presents the estimated results for model (7). Columns (1)-(3) show the results for the regressions with Loan growth (total), Loan growth (firms), and Loan growth (individuals) as the dependent variables, respectively. In all regressions, the constant term, as well as bank, region, and time fixed effects are included but not reported. Robust standard errors are presented in parentheses. NPL (firms), NPL (individuals), and NPL (total) are the ratios of non-performing loans issued to firms, to individuals, and total non-performing loans over total loans, respectively. Distance to Headquarters is the natural logarithm of the geodesic distance from the market to the headquarters. Share of loans to firms is the ratio of loans issued to firms by a bank in a market to that bank's total loans. Share of loans to individuals is the ratio of loans issued to individuals by a bank in a market to that bank's total loans. Share of branches in the market is the ratio of a bank's branches in a market to that bank's total number of branches. Number of other bank branches is the natural logarithm of the number of competitor branches in a market. Share of branches of the market is the ratio of the number of all branches in a market to the total number of bank branches. ${ }^{*},{ }^{* *}$, and ${ }^{* *}$ denote $10 \%, 5 \%$, and $1 \%$ significance levels, respectively. 